\title{
Article \\ Insight into Bortezomib Focusing on Its Efficacy against P-gp-Positive MDR Leukemia Cells
}

\author{
Tomáš Kyca ${ }^{1}$, Lucia Pavlíková ${ }^{1,2}$, Viera Boháčová ${ }^{1}$, Anton Mišák ${ }^{3} \mathbb{D}$, Alexandra Poturnayová ${ }^{1}$, \\ Albert Breier 1,4,*(D), Zdena Sulová ${ }^{1, *(D)}$ and Mário Šereš $1,2, *$
}

1 Institute of Molecular Physiology and Genetics, Centre of Biosciences, Slovak Academy of Sciences, Dúbravská cesta 9, 84505 Bratislava, Slovakia; tomas.kyca@savba.sk (T.K.); lucia.pavlikova@savba.sk (L.P.); viera.bohacova@savba.sk (V.B.); alexandra.poturnayova@savba.sk (A.P.)

2 Institute of Zoology, Slovak Academy of Sciences, Dúbravská cesta 9, 84506 Bratislava, Slovakia

3 Institute for Clinical and Translational Research, Biomedical Research Center, Slovak Academy of Sciences, Dúbravská cesta 9, 84505 Bratislava, Slovakia; anton.misak@savba.sk

4 Institute of Biochemistry and Microbiology, Faculty of Chemical and Food Technology, Slovak University of Technology in Bratislava, Radlinského 9, 81237 Bratislava 1, Slovakia

* Correspondence: albert.breier@stuba.sk (A.B.); zdena.sulova@savba.sk (Z.S.); mario.seres@stuba.sk (M.Š.); Tel.: +421-2-593-25-514 or +421-918-674-514 (A.B.); +421-2-3229-5510 (Z.S.)

Citation: Kyca, T.; Pavlíková, L.; Boháčová, V.; Mišák, A.; Poturnayová, A.; Breier, A.; Sulová, Z.; Šereš, M. Insight into Bortezomib Focusing on Its Efficacy against P-gp-Positive MDR Leukemia Cells. Int. J. Mol. Sci. 2021, 22, 5504. https://doi.org/ $10.3390 /$ ijms 22115504

Academic Editor: Alessandro Poggi

Received: 20 April 2021

Accepted: 21 May 2021

Published: 23 May 2021

Publisher's Note: MDPI stays neutral with regard to jurisdictional claims in published maps and institutional affiliations.

Copyright: (c) 2021 by the authors. Licensee MDPI, Basel, Switzerland. This article is an open access article distributed under the terms and conditions of the Creative Commons Attribution (CC BY) license (https:// creativecommons.org/licenses/by/ $4.0 /)$.

\begin{abstract}
In this paper, we compared the effects of bortezomib on L1210 (S) cells with its effects on P-glycoprotein (P-gp)-positive variant $\mathrm{S}$ cells, which expressed P-gp either after selection with vincristine ( $\mathrm{R}$ cells) or after transfection with a human gene encoding P-gp ( $\mathrm{T}$ cells). Bortezomib induced the death-related effects in the $S, R$, and T cells at concentrations not exceeding $10 \mathrm{nM}$. Bortezomib-induced cell cycle arrest in the G2/M phase was more pronounced in the $\mathrm{S}$ cells than in the $\mathrm{R}$ or $\mathrm{T}$ cells and was related to the expression levels of cyclins, cyclin-dependent kinases, and their inhibitors. We also observed an increase in the level of polyubiquitinated proteins (via K48-linkage) and a decrease in the gene expression of some deubiquitinases after treatment with bortezomib. Resistant cells expressed higher levels of genes encoding $26 \mathrm{~S}$ proteasome components and the chaperone HSP90, which is involved in $26 \mathrm{~S}$ proteasome assembly. After $4 \mathrm{~h}$ of preincubation, bortezomib induced a more pronounced depression of proteasome activity in $\mathrm{S}$ cells than in $\mathrm{R}$ or $\mathrm{T}$ cells. However, none of these changes alone or in combination sufficiently suppressed the sensitivity of $\mathrm{R}$ or $\mathrm{T}$ cells to bortezomib, which remained at a level similar to that of $\mathrm{S}$ cells.
\end{abstract}

Keywords: bortezomib; P-glycoprotein; L1210 cells; cyclin-dependent kinases; cyclins; CDK inhibitors; ubiquitination; deubiquitinases; 26S proteasome; HSP90

\section{Introduction}

Bortezomib (BOR, for the chemical structure, see Figure S1 in the supplementary files) is an approved drug (FDA and EMA [1]) for the treatment of progressive multiple myeloma and mantle cell lymphoma in patients for whom hematopoietic stem cell transplantation is not a suitable treatment [2]. A clinical study (the electronic VELCADE ${ }^{\circledR}$ OBservational Study) in a cohort of 873 patients with relapsed/refractory multiple myeloma treated with BOR after several previous treatment lines (median 2) yielded the following results [3]: (i) $69 \%$ of patients responded to treatment either partially (32\%) or completely/almost completely (37\%); (ii) the median time to response was 1.8 months, the median time to further treatment was 9.7 months, and the median interval without treatment was 7.9 months. The following side effects have been reported: not otherwise specified neuropathy (19\%) and not otherwise specified diarrhea and thrombocytopenia (17\% each). A total of 230 patients $(26 \%)$ discontinued BOR treatment due to adverse events. At baseline, 689 patients (79\%) had no peripheral neuropathy. After cycle 8, the incidence of peripheral neuropathy (in any grade) increased to $51 \%$ and in grade $3 / 4$ was $12 \%$ of patients. These 
data characterize the efficacy and risks of treatment with relapsed/refractory multiple myeloma bortezomib [3]. BOR is a dipeptidyl boronic acid (systematic name, $N-[(1 \mathrm{R})-1-$ (dihydroxyboryl)-3-methylbutyl]- $\mathrm{N} \alpha$-(2-pyrazinylcarbonyl)- $L$-phenylalaninamide) and is a highly specific proteasome inhibitor [4]. This inhibitory activity is the result of the boron in the BOR molecule attacking the catalytic center of the $20 \mathrm{~S}$ core of the proteasome with high affinity [5]. Inhibition of proteasome activity results from a tetrahedral complex that forms between the hydroxyl group of a threonine residue in the 20S $\beta 5$ subunit of the proteasome and a boronic acid moiety [6]. Therefore, the dominant mechanism of BOR action is the blockade of protein degradation by the proteasome, which leads to endoplasmic reticulum stress (ER stress), cell cycle (CC) arrest, and subsequent apoptosis [7]. Several lines of evidence suggest that BOR in combination with chemotherapy may be effective in attenuating acute lymphoblastic leukemia (ALL) characterized by dysfunctional B or T cell differentiation in children, especially for those who have developed multidrug resistance (MDR) [8,9]. The relationship of the efficacy of BOR treatment to the development of MDR can be deduced from the following findings: (i) BOR may be a substrate for the ABCB1 drug transporter (also known as P-glycoprotein-P-gp) but not for other transporters, such as $\mathrm{ABCC} 1$ or $\mathrm{ABCG} 2$ [10]; (ii) BOR may interfere with the expression of several proteins active in the cell to protect against chemical stress, e.g., the ABCC1 drug transporter [11] and P-gp [12]; (iii) expression of P-gp is associated with modulated expression of molecular chaperones active in the response of cells to ER stress and cellular protection against tunicamycin, a known ER stressor [13]. However, new findings indicate that inhibition of P-gp does not increase the efficacy of proteasome inhibitors in multiple myeloma cells [12] or in P-gp-positive B-cell precursor ALL cell lines [14].

Mouse L1210 cells are lymphocytic cells for which differentiation towards B cells has been histochemically demonstrated [15]. In parental L1210 cells (S cells), we induced P-gp expression either by adaptation to vincristine (vincristine-treated cells, $R$ cells, [16]) or by transfection with a human gene encoding P-gp (transfected cells, T cells, [17]). Both $\mathrm{P}$-gp-positive cell variants ( $\mathrm{R}$ and $\mathrm{T}$ cells) showed significant resistance to $\mathrm{P}$-gp substrates compared to $\mathrm{S}$ cells. In addition, the $\mathrm{R}$ and $\mathrm{T}$ cell lines showed significant resistance to substances not related to P-gp, such as cisplatin [18], tunicamycin [19,20], and thapsigargin [21]. P-glycoprotein has, in addition to drug efflux activity, modulatory effects that suppress the initiation of programmed cell death under the influence of cytotoxic substances (reviewed in [22]). Some additional characteristics of these cell variants are summarized in Table S1 in the supplementary files. We hypothesized that P-gp-mediated MDR is functionally linked to cellular responses to ER stress, which together modulate cellular sensitivity to various drugs [23]. Consistent with our hypothesis, we have shown that in P-gp-positive R and $\mathrm{T}$, regulatory chaperones of the unfolded protein response (UPR), are altered, which leads to resistance against tunicamycin, an ER stressor [13]. The accumulation of unfolded proteins in the ER causes ER stress and can be achieved by treating cells with several substances (ER stressors), including tunicamycin (an $\mathrm{N}$-glycosylation blocker), thapsigargin (an ER calcium ATPase inhibitor), BOR, and MG-132 (a proteasome inhibitor, for the chemical structure, see Figure S1 in the supplementary files) [24]. Since we showed that P-gp-positive R and T cells are resistant to thapsigargin [21] and tunicamycin [19,20], which cannot be explained by the transport activity of P-gp, we decided to further investigate the resistance of cells to ER stressors. For this purpose, we prepared variants of L1210 cells selected for resistance by all four ER stressors described above [25]. We found that the main molecular feature of these variants is the overexpression of the molecular chaperone GRP78/BiP, which is the central regulator of ER stress. Interestingly, overexpression of this chaperone was found in the $\mathrm{R}$ and $\mathrm{T}$ cells, but not the $\mathrm{S}$ cells, and this property appears to be critical for the resistance of $R$ and $T$ cells to tunicamycin [13]. In contrast to the reduced sensitivity of $R$ and $\mathrm{T}$ cells to thapsigargin and tunicamycin, the response of these P-gp-positive cells to BOR was similar to that of the P-gp-negative $S$ cells [25]. These results are consistent with the finding that MDR proteins (P-gp, multidrug resistance protein-1 and both breast and lung cancer resistance proteins) did not affect the cytotoxicity of BOR [26]. This finding is 
interesting because it indicates that BOR may be used alone or in combination with other antileukemic agents for the treatment of recurrent blood malignancies. Therefore, in this work, we decided to examine the effects of BOR-induced cell damage on S, R, and T cells in more detail.

\section{Results}

\subsection{Effect of Bortezomib on the Expression and Activity of P-glycoprotein}

We performed the study on three variants of L1210 cells: parental P-gp-negative S cells and two P-gp-positive R and T cells. We have studied the panel of these cells in detail in the past, and some of their characteristics important for current paper are summarized in Table S1 in the supplementary files. In both the P-gp-positive variants, in contrast to the $S$ cells, massive expression of P-gp at the mRNA and protein levels was detectable [17]. In the P-gp-positive cells, the intracellular retention of calcein, which is a substrate of P-gp, was reduced compared to that in the $S$ cells [20]. Consistent with this finding, the $R$ and $T$ cells were much less sensitive to P-gp substrates (such as VCR and doxorubicin) than $\mathrm{S}$ cells [22]. We continuously checked these characteristics during the experiments.

BOR inhibited $S, R$, and $\mathrm{T}$ cell proliferation with $\mathrm{IC}_{50}$ values of $6.0752 \pm 1.7656$, $4.7708 \pm 0.8911$, and $3.6738 \pm 0.5412$ (in $\mathrm{nM}$ ), respectively (Figure S2 in the supplementary files). This result is consistent with previously published data [25]. Because there were weakly significant differences between the $\mathrm{IC}_{50}$ values of the $\mathrm{S}$ cells and the $\mathrm{R}$ or $\mathrm{T}$ cells, it can be concluded that BOR affects $\mathrm{S}, \mathrm{R}$, and $\mathrm{T}$ cells with approximately equal efficacy. The results observed with vincristine treatment (prototypical substrate of P-gp) differed; vincristine had a much stronger effect on the $\mathrm{S}$ cells than on the $\mathrm{R}$ or $\mathrm{T}$ cells (Figure $\mathrm{S} 2$ in supplementary files).

Culturing $\mathrm{R}$ and $\mathrm{T}$ cells for $24 \mathrm{~h}$ in BOR-supplemented medium ( $5 \mathrm{nM}$ final concentration) induced a negligible decrease in P-gp transcript levels (Figure 1A). Continuation of the culture by an additional $24 \mathrm{~h}$ resulted in doubling of the P-gp gene transcript level in both the resistant cell variants. The expression of the MRP1 transporter ( $A b c c 1$ gene product) in S-cells increased by $80 \%$ and in contrast in $\mathrm{R}$ and T cells slightly decreased (about 20\%) $24 \mathrm{~h}$ after the addition of BOR at a concentration of $5 \mathrm{nM}$ (supplementary files Figure S3 panel A). The expression of the BCRP transporter (product of the $A b c g 2$ gene) increases after BOR treatment in $\mathrm{R}$ and $\mathrm{T}$ cells and remains unchanged in $\mathrm{S}$ cells. Although these alterations may cause changes in the sensitivity of our cells to BOR, their effect appears to be small, because similar sensitivity of $S, R$, and T cells to BOR was detected (supplementary sets, Figure S2). This may be due to the fact that the expression of both transporters after BOR treatment did not exceed the expression of the untreated control more than twice. However, resistance mediated by either MRP1 or BCRP is often achieved by increasing their expression 10 - to 100 -fold $[27,28]$.

Another question was whether BOR is able to reduce the efflux activity of P-gp. We used the calcein/AM retention assay described elsewhere [20] to measure P-gp efflux activity directly in living cells. BOR at concentrations of 1.0 and $10.0 \mathrm{nM}$ only slightly altered calcein retention in the $\mathrm{R}$ and $\mathrm{T}$ cells (Figure 1B). As a control, we used the known P-gp inhibitor tariqidar (at concentration $0.5 \mu \mathrm{M}$ ), which significantly increased calcein retention. 
A

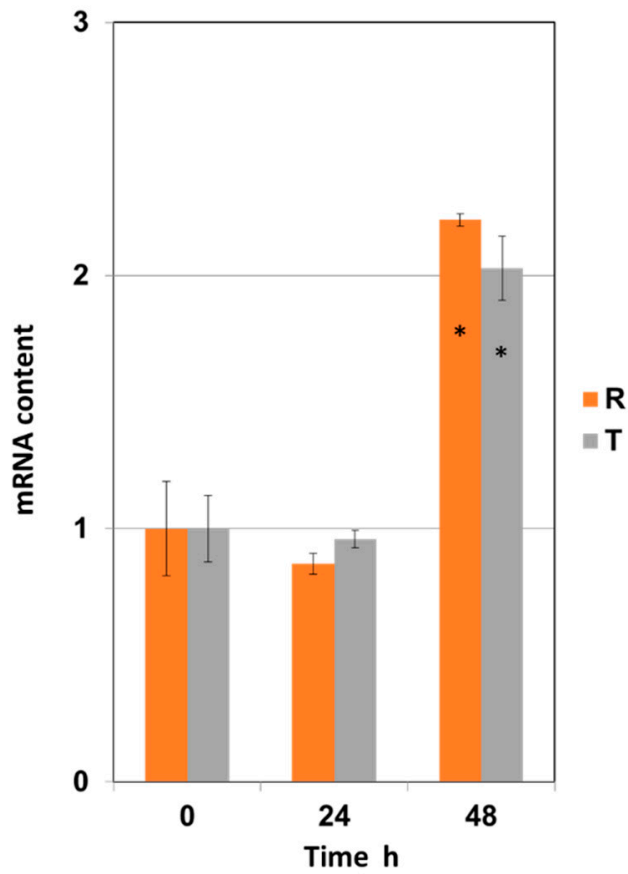

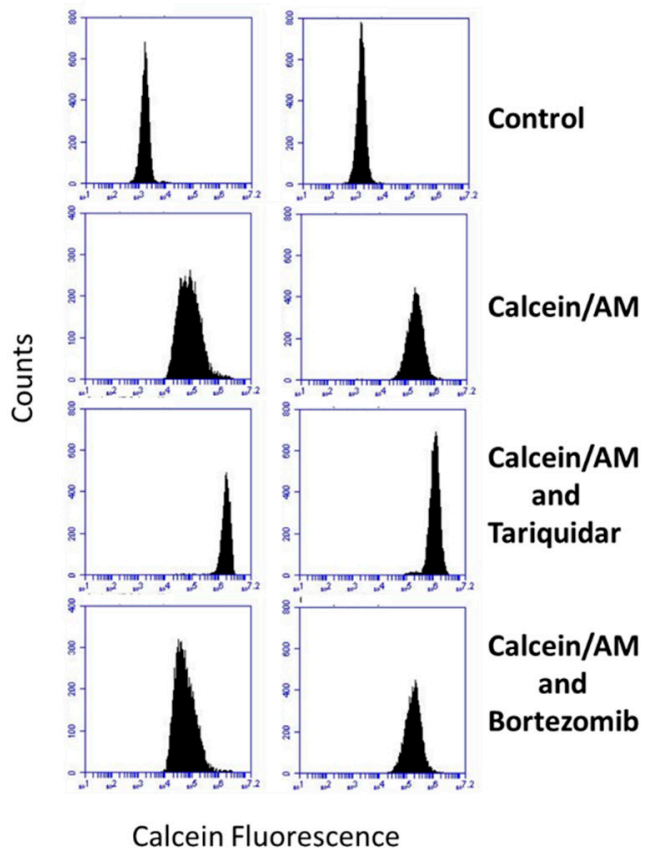

Figure 1. Panel (A): qRT-PCR detection of mRNA encoding P-gp in R and T cells cultured in medium containing BOR $(5 \mathrm{nM})$ for 24 and $48 \mathrm{~h}$. Experimental data represent the mean $\pm \mathrm{S}_{\mathrm{D}}$ of three independent experiments. Significance $*$ data differ from control (0) at $p<0.02$. Panel (B): Detection of P-gp efflux activity by calcein/AM retention assay by fluorescence cytometry. The data are representative of three independent measurements. Tariquidar, a known inhibitor of P-gp, at a concentration of $0.5 \mu \mathrm{M}$, increased calcein retention in the $\mathrm{R}$ and $\mathrm{T}$ cells [29].

In previous work, we have shown that tariquidar at this concentration restores calcein retention within $\mathrm{R}$ and $\mathrm{T}$ cells to the same extent as observed in $\mathrm{S}$ cells [29]. Another known P-gp inhibitor, verapamil, also increased calcein retention in $\mathrm{R}$ and $\mathrm{T}$ cells (not shown).

These data exclude the possibility that BOR added to $\mathrm{R}$ and $\mathrm{T}$ cells at a concentration range of 1.0-10.0 $\mu \mathrm{M}$ may significantly affect P-gp transport activity. Therefore, in additional experiments, we chose cell incubation for up to $24 \mathrm{~h}$ with a concentration of $5 \mathrm{nM}$ BOR (which corresponds to the $\mathrm{IC}_{50}$ values of the $\mathrm{S}, \mathrm{R}$, and $\mathrm{T}$ cells at $48 \mathrm{~h}$ of incubation with BOR) (Figure $\mathrm{S} 2$ in the supplementary files). Under these conditions, we did not expect to find significant changes in the expression level of the gene for P-gp or P-gp efflux activity in the $\mathrm{R}$ and $\mathrm{T}$ cells.

\subsection{Effect of Bortezomib on the Cell Cycling of the $S, R$, and $T$ Cell Variants}

In additional sets of experiments, we studied the effect of BOR $(5 \mathrm{nM})$ on the transition of cells into individual phases of the CC during a 24-h passage by measuring samples obtained at 4, 8, and $24 \mathrm{~h}$. We used a protocol of DNA staining with propidium iodide (PI) in cells fixed with $70 \%$ ethanol at $-20{ }^{\circ} \mathrm{C}$ [30]. In the absence of BOR, the $\mathrm{S}$ cells differed from the $\mathrm{R}$ and $\mathrm{T}$ cells, with a larger proportion of the S cells in the G0/G1 phase (more than $50 \%$ ) and a smaller proportion in the $S$ or G2/M phase (Figure 2).

We observed a time-dependent gradual decrease in the proportion of $S$ cells in the G0/G1 phase and a corresponding increase in the proportion of S cells in the G2/M cell phase (Figure 2). The proportion of cells in the individual phases of the CC did not change considerably in R cells passaged in the presence of BOR for 4 and $8 \mathrm{~h}$ or in T cells passaged in the presence of BOR for $4 \mathrm{~h}$. However, the passage of $\mathrm{R}$ cells for $24 \mathrm{~h}$ and $\mathrm{T}$ cells for 8 and $24 \mathrm{~h}$ in the presence of BOR led to a decreased proportion of both these cell variants in the G0/G1 phase and an increased proportion of these cell variants in the G2/M phase. 


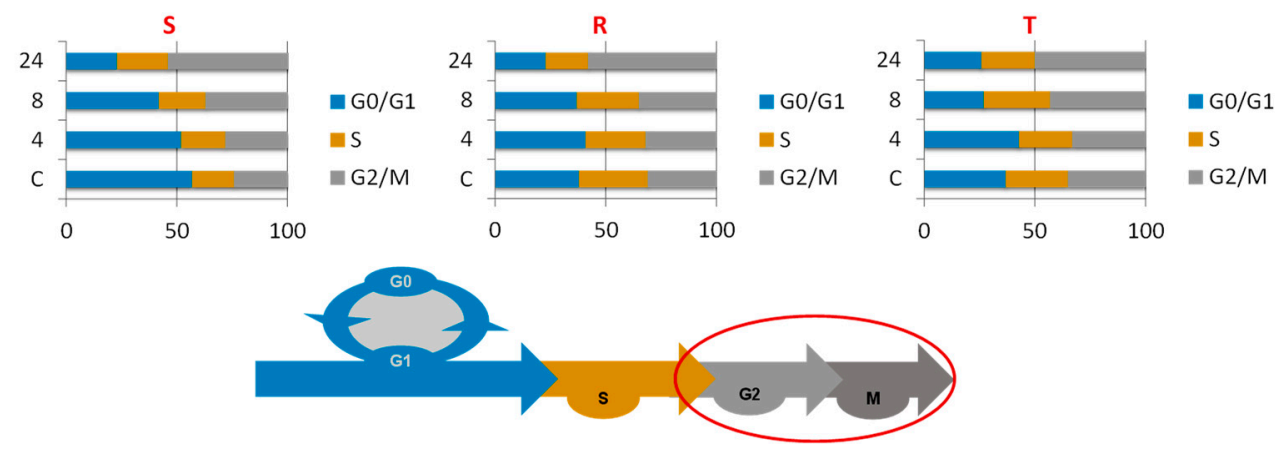

Figure 2. Effect of BOR ( $5 \mathrm{nM}$ ) on the cell cycle of $\mathrm{S}, \mathrm{R}$, and $\mathrm{T}$ cells after 4,8 , and $24 \mathrm{~h}$ of incubation compared to the untreated control (C). The data are representative of three independent measurements. The corresponding histograms generated from fluorescence cell cytometry data are documented in the supplementary files (Figure S4). The scheme at the bottom shows the progress of the cell cycle. The red ellipse indicates the points where the cell cycle was arrested under the influence of BOR.

\subsection{Effects of Bortezomib on the Expression of Proteins Associated with CC Progression in $S, R$, and $T$ Cells}

The CC consists of a series of individual events that together lead to the division of one cell into two cells. Several checkpoints (CDKs activated with cyclins) distinguish the different stages of the active CC [31]. In contrast, endogenous protein inhibitors of CDKs negatively regulate $\mathrm{CC}$ progression. The role of individual cyclins, $\mathrm{CDKs}$, and their protein inhibitors in the CC is documented in the schemes presented in Figures 3 and 4.

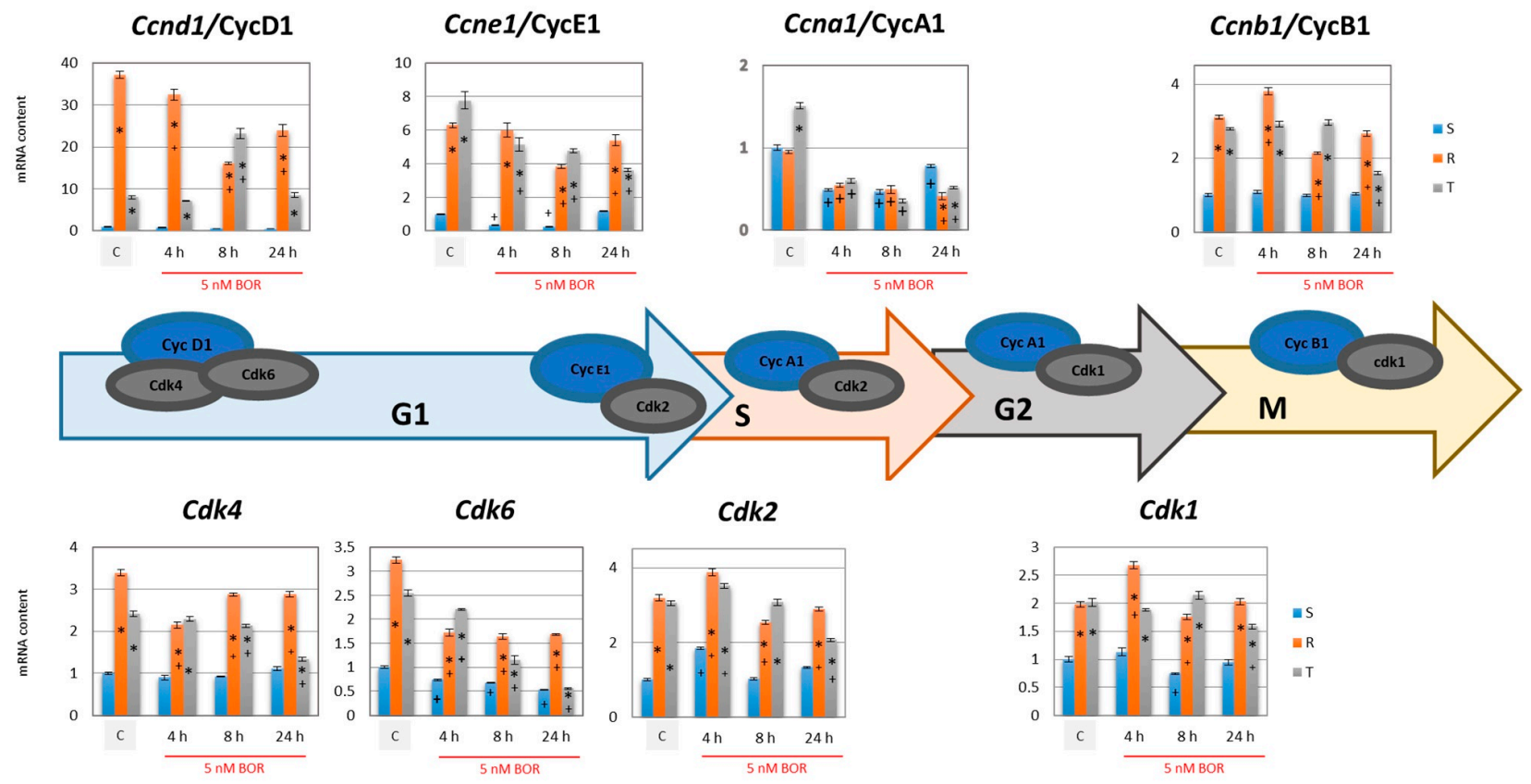

Figure 3. Effect of BOR $(5 \mathrm{nM})$ on the expression of CDKs and their activating cyclins in $S$, $R$, and T cells. $\beta$-actin was used as an internal standard and relative quantity of mRNA for $S$ cells in the absence of BOR (C) was arbitrarily taken as one. The results represent the means $\pm \mathrm{S}_{\mathrm{D}}$ of three independent measurements. Statistical significance: *-data differ from data obtained for $\mathrm{S}$ cells treated equally at $p<0.02 ;+$ - data for individual cell variants after BOR treatment differ from the untreated control at $p<0.02$. The scheme shows the progress of the cell cycle with checkpoints representing CDKs in complexes with activating cyclins. CC is regulated by cyclin-dependent threonine or serine kinases (CDKs encoded in mice by the $C d k 1, C d k 2, C d k 4$, and $C d k 6$ genes), whose activity depends on their association with activating cyclins A1, B1, D1, and E1 (encoded in mice by the Ccna1, Ccnb1, Ccnd1, and Ccne1 genes) [32]. Cyclin D1-activated CDK4 and CDK6 activities [33] and cyclin E1-activated CDK2 activity [34] are important for the progression from G0/G1 phase to S phase of CC. CDK2 and CDK1, both activated by cyclin A1, allow progression through the S and G2 phases of CC, respectively [35,36]. Cyclin B1-activated CDK1 is functional during M phase CC [36]. 


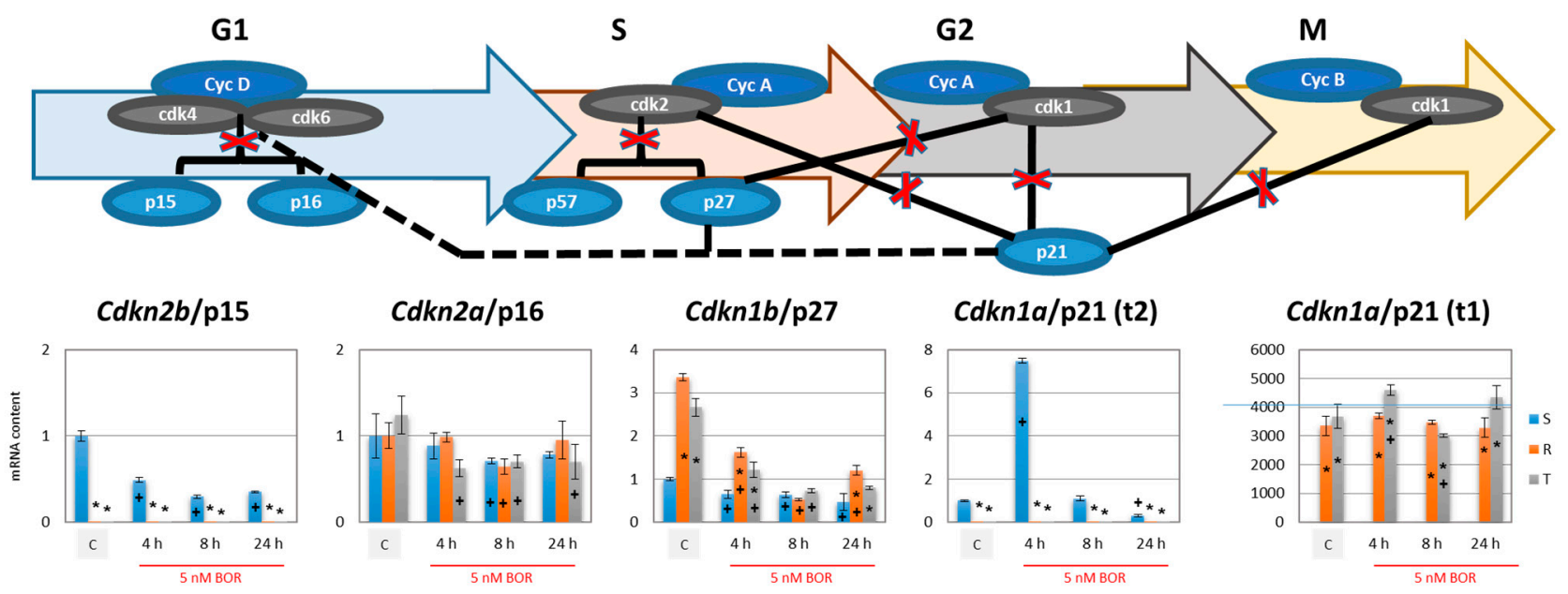

Figure 4. Effect of BOR ( $5 \mathrm{nM})$ on the expression of CDKs inhibitors (Cdkn2b, Cdkn2a, Cdkn1a, and Cdkn1b) in S, R, and T cells. Gene for $\beta$-actin was used as an internal standard and relative quantity of mRNA for $S$ cells in the absence of BOR (C) was arbitrarily taken as one. The results represent the means \pm SD of three independent measurements. Statistical significance: *-data differ from data obtained for $S$ cells treated equally at $p<0.02$; + data for individual cell variants after BOR treatment differ from those of the untreated control at $p<0.02$. In qRT-PCR detection of p57 gene (Cdkn1c) expression in all three cell variants, the p15 gene expression in $\mathrm{R}$ and $\mathrm{T}$ cells, $\mathrm{p} 21$ transcript variant $\mathrm{t} 2$ in $\mathrm{R}$ and $\mathrm{T}$ cells, and p21 transcript variant $t 1$ in $S$ cells, the measurable signal started to emerge when the number of cycles exceeded 36, which we considered a negative result. This limit was based on the recommended optimal cutoff for qPCR [37]. The scheme shows cell cycle progression with checkpoints representing CDKs with either their activating cyclins or their inhibitors. There are two families of CDK inhibitors. INK4 proteins (p15 and p16) inhibit the kinase activity of cyclin D complexes with CDK4 and CDK6, thereby attenuating the G1/S CC transition [38]. In contrast, KIP/CIP proteins (p21, p27, and p57) inhibit the kinase activities of CDK1 complexed with cyclins A and B or CDK2 complexed with cyclin A [39]. Therefore, these proteins slow CC progression in the S and G2/M phases. Paradoxically, the p21 and p27 proteins stabilize the cyclin D complex with CDK4 and CDK6 and thus may facilitate transitioning from the G0/G1 phase to the S phase [39].

The expression of cyclins B1, D1, and E1 (encoded in mice by the Ccnb1, Ccnd1, and Cone1 genes, respectively) was significantly higher in the P-gp-positive $\mathrm{R}$ and $\mathrm{T}$ cells than in the P-gp-negative $S$ cells (Figure 3). We also observed an increase in the expression of the $C d k 1, C d k 2, C d k 4$, and $C d k 6$ genes in the $\mathrm{R}$ and $\mathrm{T}$ cells compared with the $\mathrm{S}$ cells. Increased expression of CDKs and their activating cyclins is probably critical for the accelerated proliferation of the $\mathrm{R}$ and $\mathrm{T}$ cells compared to the $\mathrm{S}$ cells, which has been previously described [25]. Increased expression of the genes encoding CDK4 and CDK6 and their activator, cyclin D1, as well as CDK2, with activating cyclin E1 in P-gp-positive R and T cells (Figure 3), accelerates the shift of CC from the G0/G1 to $S$ phase. This difference in CC expression explains why the proportions of $\mathrm{R}$ and $\mathrm{T}$ cells in the GO/G1 CC phase were relatively lower than the proportion of S cells (Figure 2). Elevated expression of the Cdk2 and $C d k 1$ genes in $\mathrm{R}$ and $\mathrm{T}$ cells allowed them to pass more rapidly through the $\mathrm{S}$ and $\mathrm{G} 2$ phases, although there was no significant difference in the expression of the Ccna1 gene (encoding cyclin A1), which activated both CDKs in these phases. In the M phase, CDK1 is activated by cyclin B1, whose genes were also more highly expressed in the R and T cells than in the S cells (Figure 3). Thus, it can be concluded that the differences in the CC progression between the P-gp-negative $S$ cells and P-gp-positive $\mathrm{R}$ and $\mathrm{T}$ cells are due to specific differences in the expression of CDKs and their cyclin activators.

The expression of CDK genes under the influence of BOR oscillates around the values found for untreated cells (Figure 3). Over time, we found a monotonic decrease in expression only for $C d k 6$ for all three cell variants. Slight changes in Ccnb1, Ccnd1, and Ccne1 expression were also visible under the influence of BOR, which was more visible in $\mathrm{R}$ and $\mathrm{T}$ cells than in $\mathrm{S}$ cells. In contrast, Ccna1 expression was downregulated in all three cell 
variants after BOR treatment. This downregulation is at least partly responsible for the arrest of cells in the $\mathrm{G} 2 / \mathrm{M}$ phase.

CDK activity is negatively controlled by inhibitors of two gene families $[31,40]$. The first are INK4 (inhibitors CDK4 and 6) proteins (p15 and p16, also known as INK4B and INK4A, encoded in mice by $C d k n 2 b$ and $C d k n 2 a$ genes), which inhibit the kinase activity of cyclin D complexes with CDK4 and CDK6 (Figure 4), thereby attenuating the G1-S CC transition [38]. Second are CIP/KIP (CDK-interacting proteins/kinase-blocking proteins) proteins (p21, p27, and p57, also known as CIP1, KIP1, and KIP2, encoded in mouse by $C d k n 1 a, C d k n 1 b$, and $C d k n 1 c$ genes), which inhibit the kinase activities of CDK1 complexed with cyclin A1 and B1 or CDK2 complexed with cyclin A1 [39]. Therefore, these proteins slow $\mathrm{CC}$ progression in the $\mathrm{S}$ and G2/M phases (Figure 4).

While the p16 protein gene $(C d k n 2 b)$ was similarly expressed in all three variants of L1210 cells, the p15 protein ( $C d k n 2 a)$ was expressed only in S cells (Figure 4). Thus, it can be stated that the abandonment of the G0/G1 phase is suppressed in $\mathrm{S}$ cells by both inhibitors of CDK4 and CDK6 acting there and in R and T cells by only one. This, in turn, contributes to the understanding of why the proportion of $R$ and T cells in the G0/G1 phase of CC is relatively lower than that in S cells. The expression of the $C d k n 2 a$ gene (encoding p16) in S, $\mathrm{R}$, and T cells or the expression of the $C d k n 2 b$ gene (encoding p15) in S cells decreased after BOR treatment depending on the duration of action (Figure 4).

We did not find a measurable number of transcripts for the p57 protein in any of the three cell variants (not shown). This finding was independent of BOR treatment. In contrast, p27 expression was observed in all three cell variants, being higher in the P-gppositive variants ( $\mathrm{R}$ and $\mathrm{T}$ cells) than in the $\mathrm{P}$-gp-negative variant ( $\mathrm{S}$ cells). BOR treatment suppressed the expression of this protein (Figure 4). Similar behavior was found for the p27 protein by Western blot analysis (Figure 5).

We obtained the most interesting results in the expression of p21. The p21 protein can be expressed from two different mRNA transcript variants, which encode the same full-length protein [41]. This finding is documented in Figure S5 (supplementary files). In $S$ cells, the p21 protein was expressed from a common transcript variant (transcript t2; Figure S5 in the supplementary data), and in R and T cells, the mRNA for this variant did not exist. However, the P-gp-positive cells contained an alternative, the $\mathrm{t} 1$ transcript (Figure S5 in the supplementary data). The entire p21 protein was then detectable in both the P-gp-negative $S$ cells (in small amounts) and P-gp-positive $R$ and T cells (in high amounts) by Western blot analysis (Figure 5). Incubation of the $S$ cells with BOR for $4 \mathrm{~h}$ induced a massive increase in the level of $\mathrm{t} 2$ transcript, which was reduced to the control level upon extension of the incubation to 8 and $24 \mathrm{~h}$ (Figure 4). Accordingly, we detected an increase in p21 protein levels in BOR-treated $\mathrm{S}$ cells by Western blotting for four hours, and this increase persisted for 8 and $24 \mathrm{~h}$ (Figure 5). Fluctuating levels of t1 transcripts around the control value (in the absence of BOR) were detected in the $\mathrm{R}$ and $\mathrm{T}$ cells after BOR treatment (Figure 4). The p21 protein levels in the $\mathrm{R}$ and $\mathrm{T}$ cells tended to increase slightly (in some cases significantly) after treatment of the $\mathrm{R}$ and $\mathrm{T}$ cells with BOR (Figure 5). 


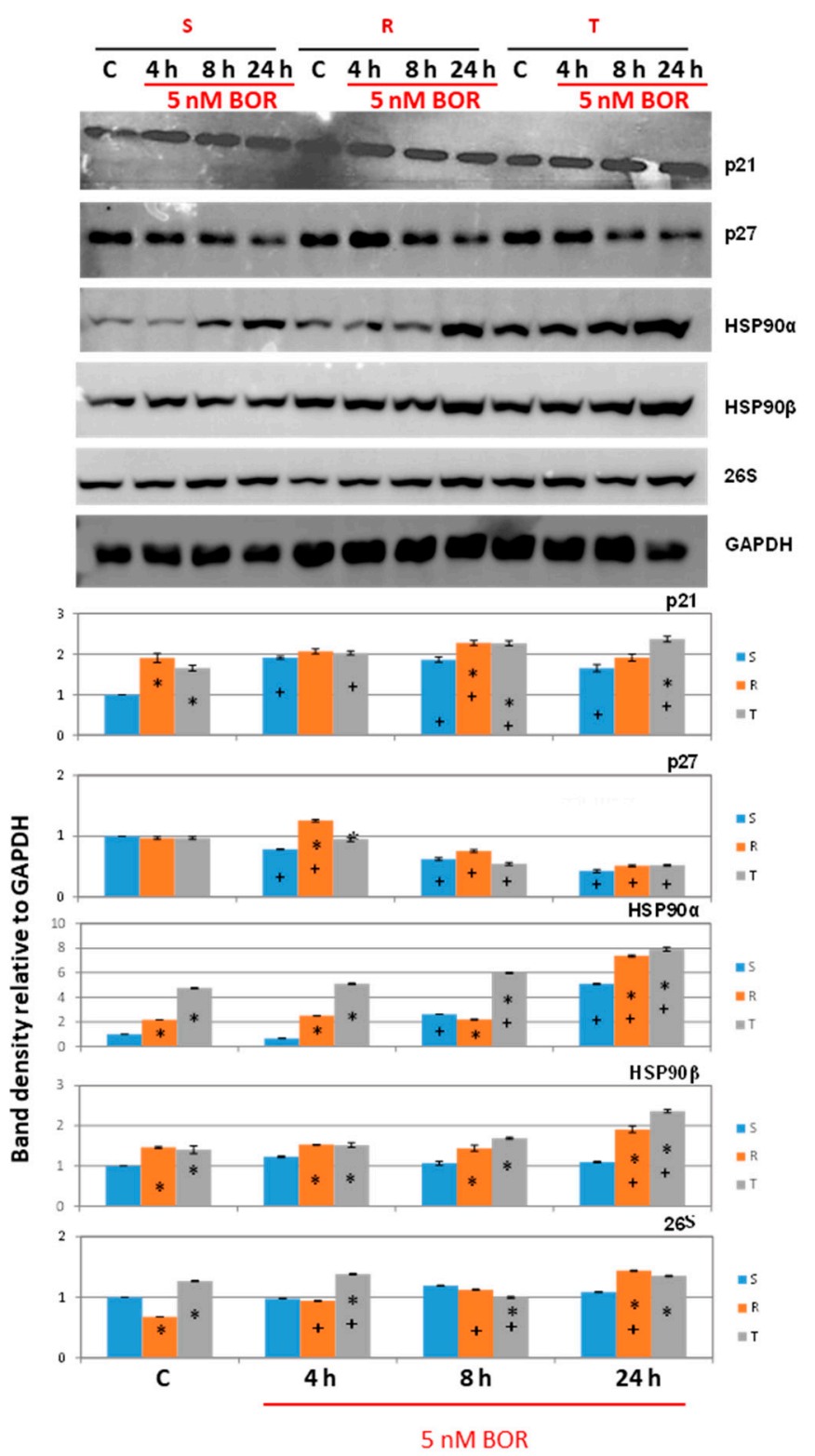

Figure 5. Levels of p21, p27, HSP90 $\alpha$, HSP90 $\beta$, and $26 \mathrm{~S}$ proteasome in S, R, and T cell variants as determined by Western blot analysis. The cells were incubated for 4,8 , and $24 \mathrm{~h}$ in growth medium in the absence $(\mathrm{C})$ or presence of BOR $(5 \mathrm{nM})$ in a $\mathrm{CO}_{2}$ incubator. GAPDH was used as an internal control. The data are representative of three independent measurements. The optical densities of the protein bands were quantified by densitometry and then expressed relative to GAPDH and summarized in bar graphs. The data represent the mean $\pm \mathrm{S}_{\mathrm{D}}$ of three independent measurements. Statistical significance: * - data differ from data obtained for $S$ cells treated equally at $p<0.02 ;+$-data for individual cell variants after BOR treatment differ from the untreated control at $p<0.02$.

\subsection{Effects of Bortezomib on the Quantity and Linkage of Ubiquitination}

As mentioned above, BOR blocks the degradation of misfolded proteins by inhibiting the activity of the $20 \mathrm{~S}$ subunit of the proteasome. Proteins labeled with polyubiquitin chains undergo proteasomal degradation [42].

Ubiquitin chains are formed by the attachment a C-terminal carboxyl group of an added ubiquitin to the $\varepsilon$-amino group of the lysine in the ubiquitin molecule previously added to the chain. Because the ubiquitin molecule contains seven different lysine residues, different linkages of ubiquitin are possible. While the best-known $\mathrm{K} 48$ linkage is accepted as a protein marker for proteasomal degradation, the K63 linkage, which is equally abundant, 
is a signal for DNA repair, endocytosis, and further processing of endocytic material [43]. Therefore, we further investigated the effect of BOR on the extent of ubiquitination of proteins with $\mathrm{K} 48$ and $\mathrm{K} 63$ linkages using ubiquitin linkage-specific antibodies. The results are presented in Figure 6.

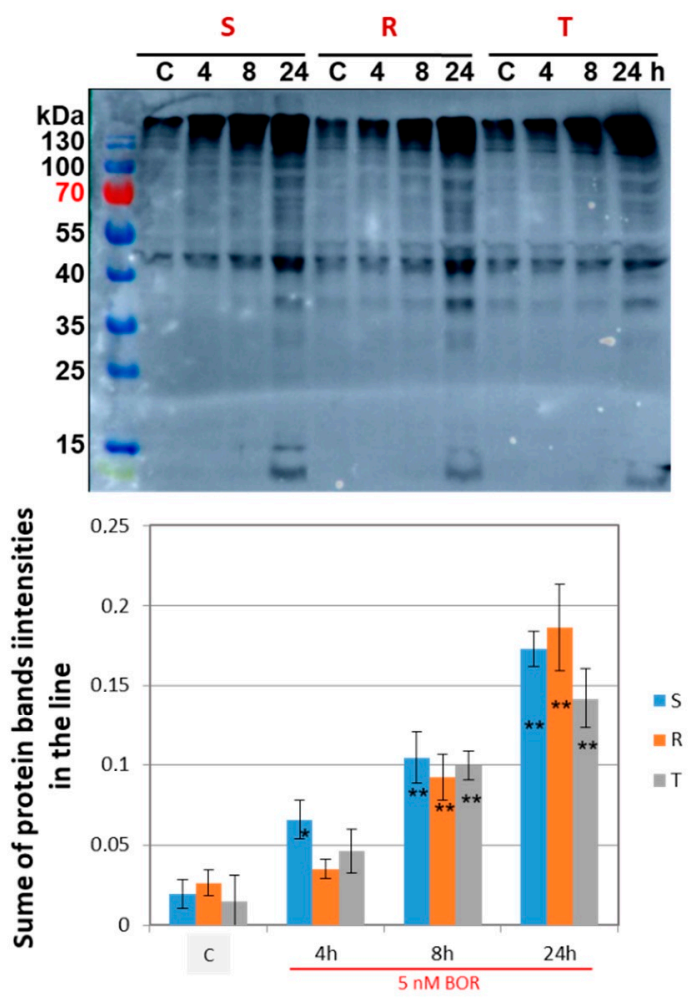

K48 linkage

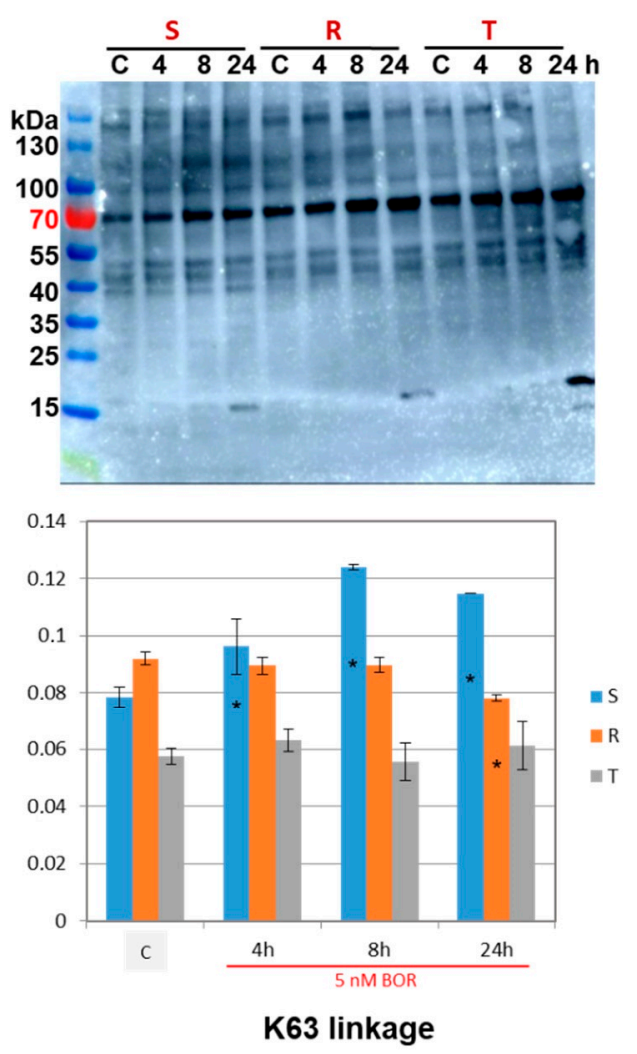

Figure 6. The levels of protein ubiquitination through $\mathrm{K} 48$ or $\mathrm{K} 63$ linkage in S, R, and T cell variants were determined by Western blot analysis using K48- and K63-linkage specific antibodies. Cells were incubated for 4, 8, and $24 \mathrm{~h}$ in growth medium in the presence of BOR $(5 \mathrm{nM})$ in an incubator with $5 \% \mathrm{CO}_{2}$ in air and were compared with untreated cells (C). The correct dosing of proteins into the individual lanes was verified in SDS-PAGE gels after staining with Coomassie G-250 (not shown). The data are representative of three independent measurements. The optical densities of all protein bands in separate lanes were quantified by densitometry and are expressed relative to the total optical density of all the bands in the entire blot. The data are summarized in bar graphs. The data are expressed as the mean $\pm S_{D}$ of three independent measurements. Statistical significance: the data for individual cell variants after BOR treatment differed from the untreated control at $p<0.02\left(^{*}\right)$ and $p<0.01\left(^{* *}\right)$.

Incubation of $S, R$, and $T$ cells in the presence of BOR led to a time-dependent increase in the proteins ubiquitinated by K48-linked chain addition. In contrast, only a slight (although significant) increase in protein ubiquitination via K63 linkage was present, and only in the $S$ cells, after 8 and $24 \mathrm{~h}$ of incubation with BOR. In the R and T cells, incubation in the presence of BOR did not change the levels of ubiquitinated proteins with this linkage.

These results demonstrate an increase in proteins ubiquitinated via K48 linkage (substrates of proteasomal degradation $[42,43]$ ) after inhibition of proteasome activity by BOR. In contrast, the levels of proteins that were ubiquitinated through the K63 linkage (which does not predispose the proteins to proteasomal degradation [42,43]) remained practically unchanged under conditions of proteasome inhibition by BOR.

\subsection{Effects of Bortezomib on the Expression of Deubiquitinating Enzymes}

In further experiments, we investigated the effect of incubating $\mathrm{S}, \mathrm{R}$, and $\mathrm{T}$ cells in medium with $5 \mathrm{nM}$ BOR for 4,8 , and $24 \mathrm{~h}$ on expression of deubiquitinases. The results are shown in Figure 7. 
A
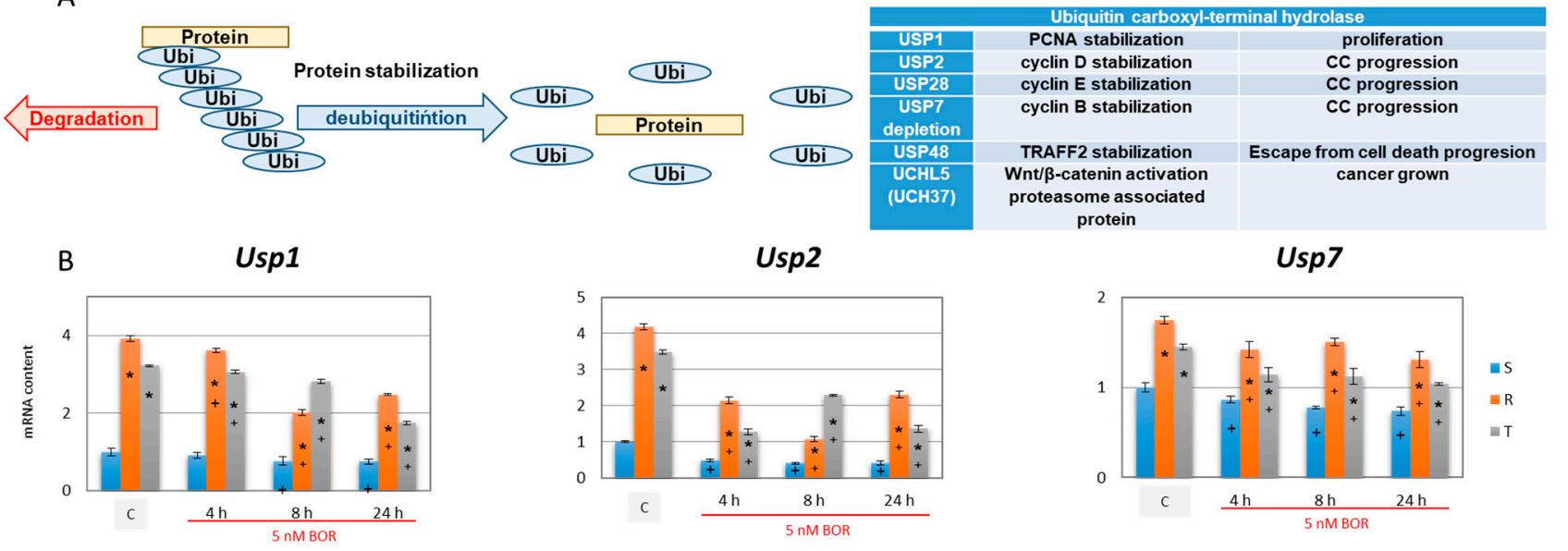

Usp48
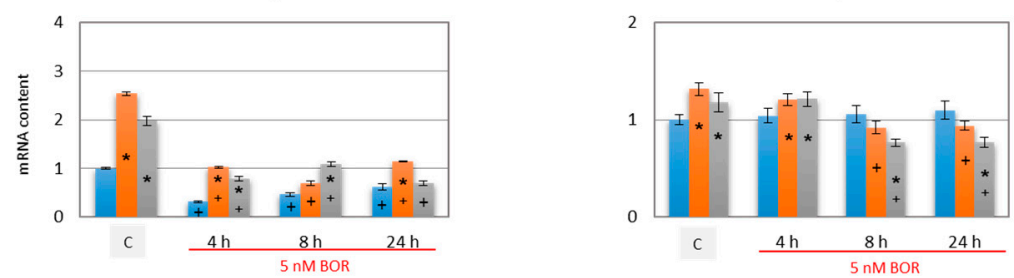

Uchl5

Figure 7. Effect of BOR ( $5 \mathrm{nM})$ on the expression of deubiquitinase genes in S, R, and T cells. Panel (A): The role of some deubiquitinases in the survival and life cycle of neoplastic cells: (i) Ubiquitin-specific protease 1 (USP1) prevents lethal stimulus, i.e., the persistence of monoubiquitinated proliferating cell nuclear antigen (PNCA) on the replication fork [44]; (ii) USP2 and USP28 stabilize cyclin D [45] and cyclin E [46], respectively; (iii) depletion of USP7 alters mitotic progression and stabilizes cyclin B [47]; USP48 stabilizes TRAF2, which acts against cell death [48,49]; and finally, UCHL5 (ubiquitin C-terminal hydrolase L5, also known as UCH37) accelerates cancer growth through upregulation of the Wnt/ $\beta$-catenin signaling pathway [50], which is a proteasome-associating protein [51]. Panel (B): qRT-PCR detection of USP1, USP2, USP7, USP28, USP48, and UCHL5 transcripts. $\beta$-actin was used as an internal standard and relative quantity of mRNA for S cells in the absence of BOR (C) was arbitrarily taken as one. The results represent the means $\pm \mathrm{S}_{\mathrm{D}}$ of three independent measurements. Statistical significance: ${ }^{*}$ - data differ from the data obtained for $\mathrm{S}$ cells treated equally at $p<0.02 ;+$ data for individual cell variants after BOR treatment differ from those of the untreated control at $p<0.02$.

Expression of deubiquitinases Usp1, Usp2, Usp7, Usp28, and Uchl5 (for explanation of the symbolism see Figure 7) was more pronounced in the P-gp-positive R and T cells than in the P-gp-negative S cells (Figure 7). A slight, although significant, increase in Usp 48 expression was observed in the $\mathrm{R}$ cells compared to the $\mathrm{S}$ cells. The increase in the latter enzyme in the T cells compared to the level in the $\mathrm{S}$ cells was insignificant. Incubation with $\mathrm{BOR}$ induced a decrease in the expression of deubiquitinases (in several cases, significantly) in the S, R, and T cells (Figure 7). This decrease was most evident in Usp2 and Usp28, which encode protein stabilizing cyclins $\mathrm{D}$ and $\mathrm{E}$, with decreases to $50 \%$ of the values found in cells without BOR treatment. Usp7 expression decreased less significantly under the influence of BOR in the $S, R$, and $T$ cells. We did not observe a decrease in the expression of Usp1, Usp48, or Uchl5 after BOR treatment in the $\mathrm{S}$ cells, but slight decreases were found in the $\mathrm{R}$ and $\mathrm{T}$ cells.

\subsection{Effect of Bortezomib on the Expression of Proteins Required for Proteasome Formation}

A functional 26S proteasome consists of a catalytic 20S core containing two inner heptamer rings with $\beta 1-\beta 7$ subunits and two outer heptamer rings with $\alpha 1-\alpha 7$ subunits as well as of a 195 regulatory cap composed of regulatory eubiquitination system [48], which is shown in Figure 7A. We further measured the expression levels of three $\beta$ subunits ( $\beta 1$, $\beta 2$, and $\beta 5$, encoded by the Psmb1, Psmb2, and Psmb5 genes) of the inner heptamer rings of the $20 \mathrm{~S}$ core of the proteasome, which have proteolytic activity. As a control, we used 
the Psma7 gene to express the $\alpha 7$ protein, which is part of the outer heptamer rings of the $20 \mathrm{~S}$ core (see proteasome structure in Figure 8A). The expression of the Pmsb5 gene, which encodes the $\beta 5$ subunit (i.e., the target of BOR), was significantly higher in the P-gp-positive $\mathrm{R}$ and $\mathrm{T}$ cells than in their P-gp-negative $\mathrm{S}$ counterparts (Figure $8 \mathrm{~B}$ ). We found similar behavior for $\beta 2$, encoded by the $P m s b 2$ gene. A significant increase in expression was observed for the Pmsb1 gene (encoding $\beta 1$ ), but the increase was less pronounced than that of the Pmsb5 and Pmsb2 genes (Figure 8B). Under the influence of BOR, depending on the time of its action, slight changes (and some significant) in the expression of all three genes were observed. The Pmsa7 gene encoding the $\alpha 7$ protein was also more highly expressed in the $R$ and $T$ cells than in the $S$ cells (Figure $8 \mathrm{~B}$ ). This finding, together with consistent data on the expression of genes encoding the $\beta 1, \beta 2$, and $\beta 5$ subunits, indicates increased production of the entire $26 \mathrm{~S}$ proteasome in P-gp-positive cells. Under the influence of BOR, the expression of the Pmsa7 gene increases monotonically with time in the $\mathrm{S}$ cells, but in the $\mathrm{R}$ and $\mathrm{T}$ cells, similar continuous growth was not evident.

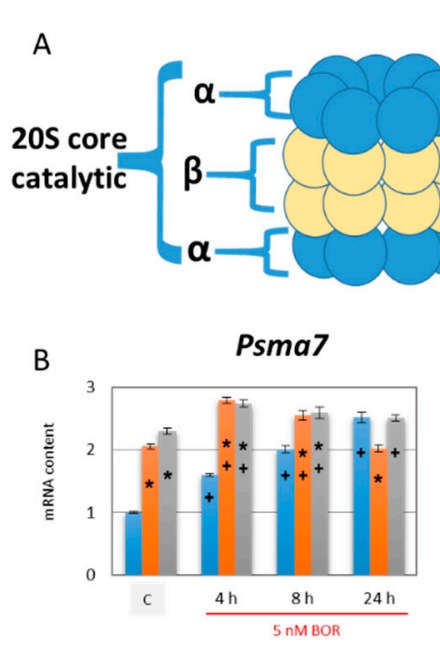

Psmb2

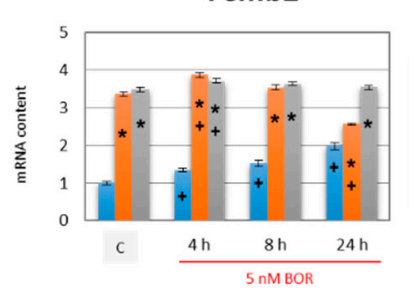

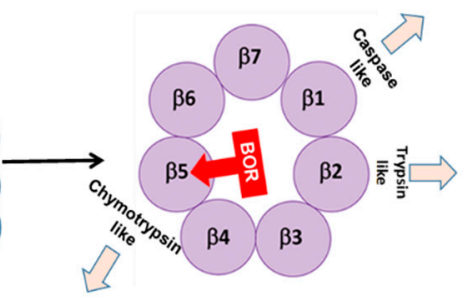

Psmb1

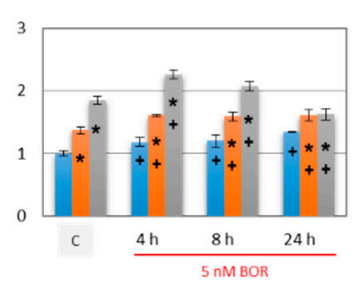

Psmb5

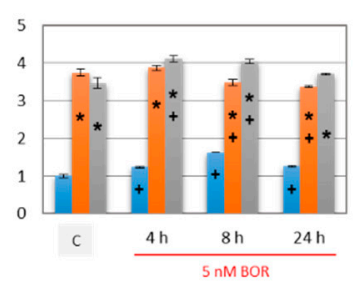

$19 S$

regulatory

$19 S$

regulatory

Figure 8. The expression of genes required for proteasome formation. Panel (A): Scheme of the structural organization of the proteasome. The structure of the $26 \mathrm{~S}$ proteasome consists of the following functional parts: a proteolytic core (20S) and a regulatory cap (19S) (reviewed in [52]). The 20S core consists of pairs of fourteen proteins encoded by 14 different genes and arranged in four heptamer rings. The outer rings contain seven $\alpha$ subunits that form a gateway for the entry of substrates into the proteolytic site, i.e., two inner rings, each formed by seven $\beta$ subunits. Three of these seven inner subunits, $\beta 1$, $\beta 2$, and $\beta 5$, are proteolytically active (with caspase-like, trypsin-like, and chymotrypsin-like activities), the latter being inhibited by BOR. This architecture creates an internal compartment where proteolytic sites are located. Therefore, the 20S subunit degrades only proteins that have entered this microspace (reviewed in [52]). Attaching the 19S cap to one or both ends of the $20 \mathrm{~S}$ forms a complete $26 \mathrm{~S}$ proteasome. 19S particles recognize polyubiquitin-tagged substrates that are then degraded. Through 19S, these proteins are first deubiquitinated and then transferred to the interior of 20S, where they are cleaved into oligopeptides. The 26S proteasome is stabilized by the HSP90 chaperone associated directly with the 20S core, affecting 20S activity $[53,54]$. The HSP90 chaperone has ATPase activity and facilitates the attachment of $19 \mathrm{~S}$ caps to the $20 \mathrm{~S}$ core. In HSP90 deficiency, the free 20S subunits become prevalent (reviewed in [55]). Panel (B): Gene expression of Psma7, Pmsb1, Pmsb2, and Pmsb5 (encoding $\alpha 7, \beta 1, \beta 2$, and $\beta 5$ proteasomal subunits, respectively) in S, R, and T cells in relation to that upon incubation with BOR. Panel (C): Gene expression of Hsp90aa and Hsp90ab (encoding HSP90 $\alpha$ and HSP90 $\beta$, respectively) in S, R, and T cells in relation to incubation with BOR. qRT-PCR was used for detection, and the 
results are shown in panels $B$ and $C$, and $\beta$-actin was used as an internal standard. Relative quantity of mRNA for $S$ cells in the absence of BOR (C) was arbitrarily taken as one. Cells were incubated with $5 \mathrm{nM}$ BOR for 4,8 , and $24 \mathrm{~h}$ before measurement, and then, total RNA was isolated. The results represent the means $\pm \mathrm{S}_{\mathrm{D}}$ of three independent measurements. Statistical significance: $*$-data differ from the data obtained for S cells treated equally at $p<0.02 ;+$ data for individual cell variants after BOR treatment differ from the untreated control at $p<0.02$. Panel (D): Detection of the complex formed by the $26 \mathrm{~S}$ proteasome and HSP90 by immunoprecipitation. Whole-cell lysates were immunoprecipitated with either anti-26S or anti-HSP90 $\alpha$ antibodies. Immunoprecipitates were subjected to Western blotting with (i) antibodies against HSP90 $\alpha$ or HSP90 $\beta$ in the case of immunoprecipitation with the anti-26S antibody and (ii) antibody against the 26S proteasome in the case of immunoprecipitation with the anti-HSP90 $\alpha$ antibody. Protein bands were visualized with 1-anti-HSP90 $\alpha$ antibody, 2-anti-HSP90ß antibody, 3-antibody against rabbit IgG, and 4-anti-26S antibody. The rabbit IgG light chain $(25 \mathrm{kDa})$ was included as an internal standard of signaling. Lines: cells prior to immunoprecipitation were incubated in the absence $\left(S, R\right.$, and $T$ cells) or presence $(5 \mathrm{nM})$ of BOR for $24 \mathrm{~h}\left(\mathrm{~S}_{\mathrm{bor}}, \mathrm{R}_{\mathrm{bor}}\right.$, and $\mathrm{T}_{\text {bor }}$ cells). The data are representative of three independent measurements.

The attachment of the $19 \mathrm{~S}$ regulatory cap to the $20 \mathrm{~S}$ proteasome core (Figure $8 \mathrm{~A}$ ) is facilitated by the molecular chaperone HSP90, in the heat shock protein family [55]. The two genes Hsp90aa and Hsp90ab encode inducible $\mathrm{HSP} 90 \alpha$ and constitutive $\mathrm{HSP} 90 \beta$, respectively [56]. Therefore, we measured the expression level of both genes in relation to BOR treatment. A higher level of expression of both genes was present in the P-gp-positive $\mathrm{R}$ and $\mathrm{T}$ cells than in the P-gp-negative S cells. Accordingly, we also found increased levels of $\mathrm{HSP} 90 \alpha$ and HSP90 $\beta$ proteins in the $R$ and T cells than we found in the $S$ cells (Figure 5). BOR treatment caused an increase in the expression of the Hsp90aa gene after 4, 8, and $24 \mathrm{~h}$ and the Hsp90ab gene after 8 and $24 \mathrm{~h}$ in the $\mathrm{S}$ cells compared to the untreated control cells. An increase in Hsp90aa expression was observed in the BOR-treated R cells after 4 and $8 \mathrm{~h}$ and in the BOR-treated T cells after $8 \mathrm{~h}$. Hsp90ab is overexpressed in the R and T cells $8 \mathrm{~h}$ after BOR administration, and its expression paradoxically decreases below the control level after $24 \mathrm{~h}$. The increase in HSP90 $\alpha$ and HSP90 $\beta$ protein levels after BOR addition detected with isoform-specific antibodies is documented in Figure 5, which shows that it was particularly pronounced after $24 \mathrm{~h}$. In parallel sets of experiments, we used an antibody that reacted with both HSP90 isoforms and obtained confirmatory results through Western blotting and immunocytochemistry with confocal microscopy (Supplementary files, Figure S6).

We also measured $26 \mathrm{~S}$ proteasome levels in $\mathrm{S}, \mathrm{R}$, and $\mathrm{T}$ cells using an anti-26S proteasome-specific antibody, which led to the identification of a $\mathrm{M}_{\mathrm{r}} \sim 100 \mathrm{kDa}$ protein in a band in the Western blot. The level of the $26 \mathrm{~S}$ proteasome in the BOR-treated and BOR-untreated cells oscillated at approximately one (Figure 5), which was arbitrarily chosen and represents the optical density of the $26 \mathrm{~S}$ protein band in untreated S-cells. The formation of the 26S proteasome is stabilized by HSP90, which is associated with the $20 \mathrm{~S}$ proteasome core $[53,54]$. Therefore, we detected an association between the $26 \mathrm{~S}$ proteasome and HSP $90 \alpha$ or HSP $90 \beta$ proteins by immunoprecipitation with anti-26S proteasome antibody and anti-HSP $90 \alpha$ antibody. The immunoprecipitate obtained using the anti-26S proteasome antibody was subjected to Western blotting with the anti-HSP90 $\alpha$ and anti-HSP90 $\beta$ antibodies, and then, the immunoprecipitate obtained with the anti-HSP $90 \alpha$ antibody was subjected to Western blotting with the anti-26S proteasome antibody. The results are summarized in Figure 8D. There was an observable trend of increasing immunoreactivity of the HSP $90 \alpha$ antibody and, in contrast, decreasing immunoreactivity of the anti-HSP90 $\beta$ antibody in immunoprecipitates obtained with the anti-26S proteasome antibody isolated from the $\mathrm{R}$ and $\mathrm{T}$ cells compared to the $\mathrm{S}$ cells. In immunoprecipitates obtained with the anti-HSP90 $\alpha$ antibody, the immunoreactivity of the anti-26S proteasome antibody was increased in the $\mathrm{R}$ and $\mathrm{T}$ cells compared to the $\mathrm{S}$ cells. Western blot detection of proteins obtained from immunoprecipitation formed doublets in some cases, which may be related to differences in posttranslational modifications of these proteins (glycosylation, ubiquitination, etc.). 


\subsection{Measurement of Proteasome Activity in $S, R$, and $T$ Cells}

We further focused on monitoring proteasome activity in cell homogenates obtained from $\mathrm{S}, \mathrm{R}$, and $\mathrm{T}$ cells. We resolved the problem caused by incubating cells in medium with $5 \mathrm{nM}$ BOR for $4 \mathrm{~h}$ or by incubating cells in medium with a known inhibitor of HSP90 function, a geldanamycin derivative [57], AADG (17-(allylamino)-17-demethoxygeldanamycin at a final concentration $1 \mu \mathrm{M}$, for the structure see Figure $\mathrm{S} 1$ in supplementary files) for $24 \mathrm{~h}$. After incubation, the cells were harvested by centrifugation, washed extensively in phosphate-buffered saline (PBS) to remove inhibitors, and then used to measure proteasome activity. An ab107921 proteasome activity assay kit (Abcam, Cambridge, UK) was used for the measurement according to the manufacturer's instructions [58]. The specificity of the test was ensured by (i) adding a specific substrate of the $26 \mathrm{~S}$ proteasome, Suc-LLVY-AMC (for the structure, see Figure $\mathrm{S} 1$ in the supplementary files) and (ii) adding specific $26 \mathrm{~S}$ proteasome inhibitor MG-132 (for the structure, see Figure S1 in supplementary files). The substrate was labeled with fluorescently active 7-amino-4-methylcoumarin (AMC), which is released by chymotrypsin-like proteasome activity. MG-132 was used to distinguish other proteolytic activities that can lead to similar cleavage of the substrate.

Cutting AMC from the substrate and plotting the BOR effect as a function of time for 90 min revealed a straight line (Figure S7A in the Supplementary files), and similarly, a straight line was obtained when plotting the AADG effect measured for 75 min (Figure S7B in the supplementary files), both indicating a zero-order reaction that is typical of enzyme catalysis. In previous work, we observed similar behavior when measuring proteasome activity in L1210 cell variants [25]. This behavior makes it possible to determine the initial reaction rate of the proteasomal cleavage of a substrate, which is constant throughout the measurement, as the slope of the respective line. The values of the initial rates of proteasome activity are documented in Figure 9.

The proteasome activity in the homogenates obtained from $S, R$, and $T$ cells reached nearly the same level (Figure 9). Four hours of incubation of the $S$ cells with $5 \mathrm{nM}$ BOR caused a decrease in $26 \mathrm{~S}$ proteasome activity to approximately $25 \%$ of the baseline (Figure $9 \mathrm{~A}$ ). In contrast, the effect of BOR was significantly weaker on the R cells, which after incubation with BOR exhibited approximately $83 \%$ of the original activity. The value of the decrease in proteasome activity induced by BOR in the T cells was between the values obtained with the $S$ and $R$ cells and reached approximately $50 \%$ of the original value (Figure $9 \mathrm{~A}$ ).

Incubation of $\mathrm{S}$ cells with $1 \mu \mathrm{M}$ AADG caused an increase in $26 \mathrm{~S}$ proteasome activity, to $133 \%$ of the original activity (Figure $9 \mathrm{~B}$ ). Under the same conditions, the $26 \mathrm{~S}$ proteasome activity in $\mathrm{R}$ and $\mathrm{T}$ cell homogenates changed very little (approximately $88 \%$ for the $\mathrm{R}$ cells and approximately $100 \%$ for the T cells) compared to controls cultured in the absence of AADG (Figure 9B). 


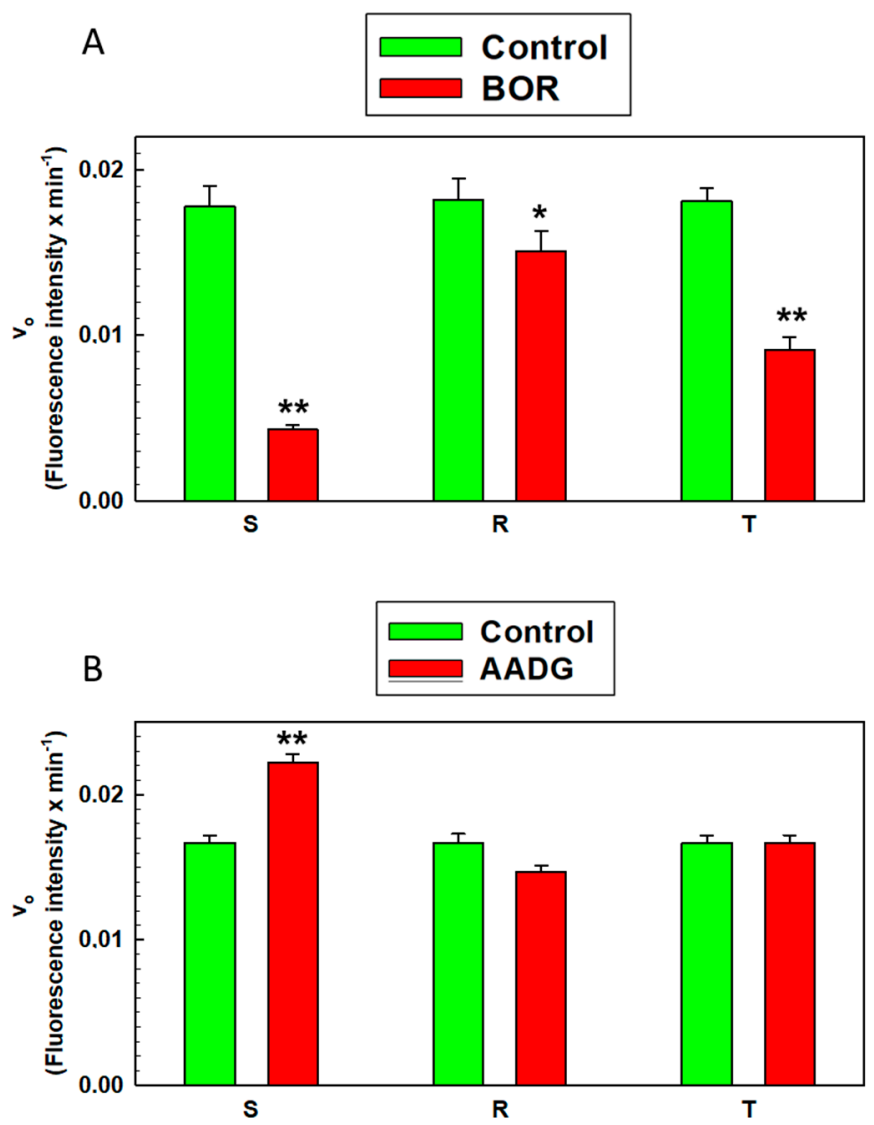

Figure 9. Proteasome activity was measured by an ab107921 proteasome activity assay kit. Panels $(\mathbf{A}, \mathbf{B})$ represent measurements of the $26 \mathrm{~S}$ proteasome activity in $\mathrm{S}, \mathrm{R}$, and $\mathrm{T}$ cells after incubation with either $5 \mathrm{nM}$ BOR (for the structure, see Figure S1 in the supplementary files) for $4 \mathrm{~h}$ or $1 \mu \mathrm{M}$ AADG (for the structure, see Figure S1 in the supplementary files) for $24 \mathrm{~h}$. The data represent the computed values $\pm \mathrm{SD}$ as determined accounted from the linear regression results shown in Figure S7 (in the supplementary files) for three independent measurements. Significance: the value differed from the control (untreated cells) at ${ }^{* *}-p<0.01$ or ${ }^{*}-p<0.02$.

\section{Discussion}

$\mathrm{BOR}$, a proteasome inhibitor, is a progressive therapeutic agent currently used clinically to treat multiple myeloma and mantle cell lymphoma as indicated by their FDA and EMA approval [1,2]. Clinical/experimental studies have shown that BOR alone or in combination with other drugs may be effective in better management of other types of human hematological malignancies (reviewed in [4]).

However, neoplastic cells in response to previous treatment or due to the nature of the tissue from which they were transformed may have activated mechanisms that protect them from cell death induced by various therapeutics. There are a wide variety of mechanisms that allow cells to cope with toxic substances [22,59]. The expression of drug transporters in the ABC gene family, of which P-gp is the best known and the most common [22], is the predominant cause of chemotherapy failure in malignancy.

Therefore, we sought to determine whether P-gp-overexpressing cells respond to BOR with a similar or different intensity as their P-gp-negative counterparts. In this respect, it was interesting that the effect of BOR on the P-gp-positive R and T cells was even more pronounced than that on the P-gp-negative $\mathrm{S}$ cells (Figure $\mathrm{S} 2$ in the supplementary files). BOR is considered a P-glycoprotein substrate [10], which was expected to result in reduced BOR sensitivity of the $R$ and $T$ cells compared to the $S$ cells, which was not confirmed by the data, as shown in Figure S2 (in the supplementary files). However, MDR transporters do not affect BOR cytotoxicity [26]. Measurements of P-gp transport activity by calcein/AM 
assay did not show elevated calcein retention of either the $\mathrm{R}$ or $\mathrm{T}$ cells in the presence of BOR. Both of these findings suggest that BOR used at these concentrations to treat $R$ and $T$ cells was not removed from the cells by P-gp and was not efficient enough to affect P-gp-mediated transport. Therefore, it is unlikely that BOR is a suitable substrate for P-gp expressed from the mouse genome in $\mathrm{R}$ and cells or from a plasmid with the human gene in T cells.

We previously described several differences between P-gp-positive $\mathrm{R}$ and $\mathrm{T}$ cells and their P-gp-negative $S$ counterparts, which, in conjunction with or independent of P-gp efflux activity, modulated changes in the overall sensitivity of the $\mathrm{R}$ and $\mathrm{T}$ cells to different substances [13,18-22,25]. These changes may include a lower proportion of $R$ and $T$ cells than S cells in the G0/G1 phase of the cell cycle when none of the three are treated with BOR (Figure 2). This may be due to higher expression levels of genes for the major regulators of $\mathrm{G} 1$ phase exit in the $\mathrm{R}$ and $\mathrm{T}$ cells than in the $\mathrm{S}$ cells, namely, CDK4 and CDK6, which are both activated by cyclin D1 [33], and CDK2, which is activated by cyclin E1 [34], as documented in Figure 3. The faster exit from the G1 phase of the cell cycle was also associated with very low expression of the p15 inhibitor of CDK4 and CDK6 [38] in the R and $\mathrm{T}$ cells compared to the $\mathrm{S}$ cells (Figure 4).

Another reason that $\mathrm{R}$ and $\mathrm{T}$ cells exit the G1 phase rapidly relates to the higher content of the p21 protein in these cells (Figure 5). In addition to being an inhibitor of CDK2 and CDK1 when in complex with cyclin A1 or CDK1 when in complex with cyclin B1 (both cyclins are active in the S, G2, and M phases [39], see scheme on Figure 4), p21 also regulates G1 phase events. Cyclin D1 and p21 have been shown to stabilize each other through the formation of the cyclin D1-CDK4 (6)-p21 complex, and the uncomplexed proteins are readily degraded $[39,60]$.

Although $S, R$, and $T$ cells show similar sensitivity to $B O R$ ( $\mathrm{IC}_{50}$ values in the range of 4.3-7.8, 3.9-5.7, and 3.1-4.2 $\mathrm{nM}$ for the $\mathrm{S}, \mathrm{R}$, and $\mathrm{T}$ cells, respectively), a more detailed analysis of the cellular response features during CC progression after BOR treatment revealed several differences between these variants:

1. S cells showed a greater tendency to enter $C C$ arrest in the G2/M phase than $R$ or $T$ cells, which manifests as $S$ cells arrested within $4 \mathrm{~h}$ of treatment (Figure 2).

2. The gene expression of cyclins B1, D1, and E1 and all four CDKs was higher in the $\mathrm{R}$ and $\mathrm{T}$ cells than in the $\mathrm{S}$ cells (Figure 4). This expression level was maintained for CDK1 and CDK2 (active in S and G2/M phase [35,36]) and cyclins B1 (activating CDK1 in the M phase [36]), D1, and E1 (both activating CDK4 and CDK6 in the G1 phase $[33,34])$ even $24 \mathrm{~h}$ after the addition of $5 \mathrm{nM}$ BOR. In the $\mathrm{T}$ cells but not in the $\mathrm{R}$ cells, $24 \mathrm{~h}$ after the addition of BOR, the expression levels of the CDK4- and CDK6-encoding genes approached the levels in the $\mathrm{S}$ cells. Cyclin A1 (activating CDK2 in the $S$ phase [35] and CDK1 in the G2 phase [36]) gene expression levels decreased after treatment of all three cell variants with BOR (Figure 4).

3. $C d k n 2 b$ (encoding the $\mathrm{p} 15$ inhibitors CDK4 and CDK6 [38]) was expressed at a lower level in the $\mathrm{R}$ and $\mathrm{T}$ cells than in the $\mathrm{S}$ cells and persisted at this level even after BOR treatment, although the expression of this gene in the $S$ cells decreased (Figure 4). Higher expression levels of the Cdkn1b gene (the p27 inhibitor CDK1 and CDK2 and stabilizer of the CDK4 and CDK6 complexes formed with cyclin D1 [39]) was observed in the $\mathrm{R}$ and $\mathrm{T}$ cells than in the $\mathrm{S}$ cells, a trend that persisted even after BOR treatment, although the gene expression levels for this protein decreased in all three cell variants (Figure 4). Consistent with its gene expression, the p27 protein level also decreased in all three cell variants after treatment with BOR (Figure 5). Expression of a multimodal modulator of CDKs encoded by the Cdkn1a gene (p21, an inhibitor of CDK1 and CDK2 and stabilizer of complexes formed by CDK4 or CDK6 with cyclin D1 [39,60]) is expressed from a common $\mathrm{t} 2$ transcript variant in $\mathrm{S}$ cells and from an alternative $\mathrm{t} 1$ transcript variant in R and T cells (Figure S5 in supplementary files).

It can be emphasized that, although the regulation of the course of the $\mathrm{CC}$ is very complex, the changes in CDK, cyclin, and CDK inhibitor expression described above 
correspond to differences in the $\mathrm{CC}$ in $\mathrm{S}, \mathrm{R}$, and $\mathrm{T}$ cells and their specific responses and BOR therapy.

The reason that $\mathrm{p} 21$ is expressed from the alternate $\mathrm{t} 1$ transcript in the P-gp-positive $\mathrm{R}$ and $\mathrm{T}$ cells has not been fully elucidated. However, this result may be related to the expression and function of p53 in these cells. We measured a set of experimental data in which the expression of the p53 protein was decreased in the R and T cells but not in the $\mathrm{S}$ cells, similar to previous findings showing that the presence of this protein appeared to be reduced in both P-gp-positive cell variants [61]. While the expression of p21 that is encoded in the common $t 2$ transcript is strictly dependent on the presence of p53 [62], the expression of p21 that is encoded in the alternative transcript $\mathrm{t} 1$ is also apparent in the absence of p53 [41]. Although it is generally recognized that p21 expression is commonly induced by p53, p53-independent induction of p21 in neoplastic cells has been found in the regulatory mechanisms of cells and may be associated with genomic instability caused by the deregulation of the replication process in cancer cells [63]. The expression of p53 in $S, R$, and T cells and its changes in response to treatment with BOR and other inducers of ER stress are currently being intensively studied in our laboratory, and preliminary results confirm the differences between P-gp-positive $\mathrm{R}$ and $\mathrm{T}$ cells and their P-gp-negative $S$ cell counterparts. $p 21$ is evidently encoded in multiple transcriptional variants in both mice [64] and humans [41]. Despite the differences in the variants, the coding sequences are identical and therefore produce the same protein [65]. Transcript variant differences are based on different $5^{\prime}$-untranslated regions. These regions play crucial roles in regulating translation, which suggests that the expression of p21 that is encoded these variants is controlled differently at the translation level. It has been shown that $5^{\prime}$-upstream open reading frames in the $5^{\prime}$-untranslated region of gene transcription variants can increase translation during amino acid deprivation-induced stress [65]. It can therefore be assumed that under stress conditions, genes may be expressed through a different transcript variant than that transcribed in unstressed cells. Therefore, we speculate that the expression of the $\mathrm{t} 1$ transcript in the $\mathrm{R}$ and $\mathrm{T}$ cells is due to the response of these P-gp-positive cells to stress induced by cytotoxic substances.

Suppressed degradation of ubiquitinated unfolded proteins in BOR-inhibited proteasomes results in the accumulation of these proteins in the cells. This has been demonstrated, e.g., in BH4 acute promyelocytic leukemia cells [66]. In our experiments, we observed an increase in ubiquitinated proteins with specific K48 linkage of the ubiquitin chain (Figure 6). Polyubiquitination through this type of linkage is recognized by the $26 \mathrm{~S}$ proteasome, and the labeled protein undergoes subsequent degradation [67]. In contrast to the K48 linkage, the polyubiquitination of proteins via the $\mathrm{K} 63$ chain, which is a signal for endocytosis and DNA repair [43], was increased slightly only in the $S$ cells and appeared to be independent of BOR treatment in the R and T cells (Figure 6).

Protein ubiquitination is a dynamic, precisely controlled, and reversible process. While ubiquitination is a modification realized by the cooperation of three types of enzymes, ubiquitin activating enzymes, ubiquitin conjugating enzymes, and ubiquitin ligating enzymes, the reversal of ubiquitination of client proteins is ensured by deubiquitinases [68]. Deubiquitination can considerably contribute to the stabilization of proteins, promoting the proliferation and aggressive characteristic of neoplastically transformed cells. Some of these deubiquitinases are directly involved in the mechanism of survival and proliferation of neoplastic cells (see Figure 7). Higher expression of deubiquitinase genes (Usp1, Usp2, Usp7, Usp28, Usp48, and Uch15) was observed in the P-gp-positive R and T cells than in the $S$ cells (Figure 7). This outcome was most pronounced for the genes for Usp1, Usp2, and Usp28. The deubiquitinase USP1 protects against response to the death signal, which causes persistence of monoubiquitinated PNCA on the replication fork. In the absence of USP1, persistent monoubiquitination of PCNA on the replication fork results in cell death [44]. Therefore, USP1 facilitates DNA replication in cells, which enables their proliferation. USP2 and USP28 stabilize cyclin D1 [45] and E1 [46], both of which are required for the activation of CDKs in the G1 phase of the CC (see scheme in Figure 3). It is therefore 
not surprising that the deubiquitinase genes USP1, USP2, and USP28 are more highly expressed in $\mathrm{R}$ and $\mathrm{T}$ cells, which proliferate faster [25] and remain expressed at lower levels in S cells, which are more retained in G0/G1 phase (Figure 2). The expression of deubiquitinase genes tended to decrease after BOR treatment (Figure 7). This outcome may then contribute to the increase in ubiquitinated proteins with a K48 linkage after BOR treatment (Figure 6), which are degraded to a lesser degree by the $26 \mathrm{~S}$ proteasome and are less extensively deubiquitinated.

The proteasome (26S) is a complicated multiprotein complex that degrades poorly assembled proteins previously labeled with ubiquitin $[69,70]$. It consists of a catalytic subunit, 20S, and a control subunit, 19S (reviewed in [52]). The structure of the proteasome is shown in the scheme in Figure 8A. The subunits of the 20S catalytic core, $\beta 1, \beta 2, \beta 5$ (components of inner heptamers), and the $\alpha 7$ (component of outer heptamers) were more highly expressed in the P-gp-positive $\mathrm{R}$ and $\mathrm{T}$ cells than in the P-gp-negative $\mathrm{S}$ cells (Figure 8B). Incubation of the S, R, and T cells with BOR led to slight increases in the expression of Psma7, Psmb1, $P s m b 2$, and Pmsb5 genes encoding the $\alpha 7, \beta 1, \beta 2$, and $\beta 5$ subunits of the $26 \mathrm{~S}$ proteasome, respectively (in several cases, the expression differences were significant). However, these changes do not appear to be sufficient to change the overall proteasome activity in the cells to the extent that the cellular response to BOR is altered. Consistent with this assumption, Western blot analysis revealed only small, albeit in some cases significant, changes in the expression of proteins with immunoreactivity to the $26 \mathrm{~S}$ antibody (Figure 5).

HSP90 $\alpha$ and $\beta$ chaperones are key regulators of various processes in eukaryotic cells that facilitate client protein formation into common intermolecular complexes with a specific biological role, such as the 26S proteasome [71]. HSP90 is conjugated to the $20 \mathrm{~S}$ core of the proteasome and facilitates the attachment of $19 \mathrm{~S}$ regulatory caps, thereby completing the $26 \mathrm{~S}$ proteasome complex [55]. In agreement with the roles of these chaperones, we performed immunoprecipitation assays and demonstrated a direct interaction between the $26 \mathrm{~S}$ proteasome and HSP90 $\alpha$ or HSP90 $\beta$ (Figure 8D). The function of the $19 \mathrm{~S}$ structure is to recognize polyubiquitinated proteins with the K48 linkage and move them into the $20 \mathrm{~S}$ core for degradation [51]. If the 19S cap is not attached, the 20S core alone is capable of splicing proteins, but in a ubiquitin-independent manner [52]. The expression of the HSP90 chaperone, which exists in mice as either inducible HSP90 $\alpha$ (encoded by the Hsp90aa gene) or constitutive HSP90 $\beta$ (encoded by the Hsp90ab gene) [72], is higher in P-gp-positive cells at both the mRNA (Figure 8) and protein levels (Figure 5, Figure S6 in supplementary files). In our cell experiments, incubation with BOR for $8 \mathrm{~h}$ caused an increase in the transcripts of both HSP90 genes (Figure 8). After $24 \mathrm{~h}$, the level of these transcripts was close to that of the unaffected controls. Incubation of the cells in the presence of BOR led to an increase in the HSP90 $\alpha$ protein content in all three L1210 cell lines and HSP90 $\beta$ in the P-gp-positive R and $\mathrm{T}$ cells (Figure 5).

The data presented in the previous paragraph suggest that subunits for the construction of the $26 \mathrm{~S}$ proteasome are expressed in $\mathrm{S}, \mathrm{R}$, and T cells and that the chaperone HSP90, which is necessary for the attachment of $19 \mathrm{~S}$ caps to the $20 \mathrm{~S}$ core, is also conjugated to the $26 \mathrm{~S}$ proteasome (Figures 5 and 8 ). Next, we verified the functionality of the proteasome. Specifically, we determined the proteolytic activity of the $26 \mathrm{~S}$ proteasome. Consistent with previous work [25], measurement of proteasome activity in cell homogenates provided a linear time course, indicating a zero-order reaction (Figure S7 in the supplementary files). $\mathrm{S}$ cells incubated with BOR showed reduced proteasome activity to one-quarter of the value of the untreated control cells (Figure 9A). In the $\mathrm{R}$ and $\mathrm{T}$ cells, the decrease was less extensive, and the activity in these cells after incubation with BOR reached approximately $83 \%$ and $50 \%$ of the activity in the untreated control cells. This result may be related to the higher levels of expression of the proteasome $\alpha$ and $\beta$ subunits and HSP90 chaperone in the P-gp-positive cells than in the P-gp-negative cells (Figures 5 and 8). We also used the geldanamycin derivative AADG, which is a known inhibitor of HSP90 [57], and hypothesized that the activity of the $26 \mathrm{~S}$ proteasome would decrease. However, the proteasome activity increased in the $S$ cells and did not change in the $R$ and $T$ cells (Figure 9B). These results are 
difficult to explain unambiguously, but the following considerations seem relevant. When HSP90 is blocked with AADG, the 19S caps, which are required for the recognition of K48 polyubiquitinated proteins, do not attach to the 20S cores of the proteasome [73]. However, the $20 \mathrm{~S}$ core exhibits proteolytic activity without specificity for ubiquitinated proteins [52]. The specific 26S proteasome substrate Suc-LLVY-AMC [58] is a mimetic that docks at the proteolytic cleavage site but does not reflect the ubiquitinated protein form; therefore, it can be cleaved directly by the $20 S$ proteasome core. Then, in cells treated with AADG, the 20S core predominated over complete $26 \mathrm{~S}$ proteasomes. These cores can cleave Suc-LLVY-AMC faster than the proteasome. The possible acceptance of this hypothesis is enhanced by the fact that geldanamycin increased the relative activity of the 20S proteasome core [73]. In R and T cells with a higher content of HSP90, the inhibitory effect of AADG was less pronounced; therefore, we did not observe an acceleration of Suc-LLVY-AMC cleavage.

\section{Materials and Methods}

\subsection{Cells and Cultivation Conditions}

The parental P-gp-negative mouse leukemia L1210 cell line (ACC-123 was obtained from the Leibniz-Institut DSMZ-Deutsche Sammlung von Mikroorganismen und Zellkulturen $\mathrm{GmbH}$, Braunschweig, Germany) and is herein referred to as the $\mathrm{S}$ cell line. The $\mathrm{P}$-gp-positive cell variants, $\mathrm{R}$ cells, were obtained by selecting $\mathrm{S}$ cells with vincristine. The P-gp-positive T cell variant was obtained by transfection with plasmid 10,957 obtained from Addgene (Watertown, MA, USA) containing cDNA for full-length P-gp (pHaMDRwt [74]). These three cell lines (the characterization of which is described in previous articles $[13,17-20,25,61])$ were used in the present study. The cells were cultured in RPMI 1640 medium containing $8 \%$ fetal bovine serum and $20 \mu \mathrm{g} / 1$ gentamicin (from Gibco, Langley, OK, USA) in a humidified atmosphere with $5 \% \mathrm{CO}_{2}$ in air at $37^{\circ} \mathrm{C}$. These $\mathrm{L} 1210$ cell variants were cultivated in the presence of $5 \mathrm{nM}$ BOR (from the Merck group via MERCK spol. S.r.o., Bratislava, Slovak Republic) for different time intervals $(4,8$, and $24 \mathrm{~h})$ prior to the experiment.

\subsection{Cell Viability Tested by MTT Assay}

Cells $\left(5 \times 10^{4}\right.$ cells/well) were cultured in the presence or absence of either BOR (1-100 nM) or vincristine (1-1000 nM), which was administered directly into $200 \mu \mathrm{L}$ of culture medium in 96-well cell culture plates. After $48 \mathrm{~h}$, cell viability was assessed by MTT assay based on the reduction of MTT ([3-(4,5-dimethyldiazol-2-yl)-2,5-diphenyltetrazolium bromide) to insoluble purple formazan, the crystals of which were subsequently dissolved by dimethyl sulfoxide. Details of the assay are described elsewhere [25]. Absorbance at $540 \mathrm{~nm}$ was measured using a Universal Microplate mQuant spectrophotometer (BioTek Instruments, Inc., Winooski, VT, USA).

\subsection{Measurement of P-gp Transport Activity by Calcein/AM Retention Assay}

$\mathrm{R}$ and $\mathrm{T}$ cells $\left(5 \times 10^{5}\right)$ were washed twice in PBS containing $0.1 \%$ bovine serum albumin and then resuspended in $500 \mu \mathrm{L}$ of the same buffer in the absence or presence of BOR (1 and $10 \mathrm{nM}$ ). Calcein/AM to a final concentration of $0.1 \mu \mathrm{M}$ and PI to a final concentration of $0.9 \mu \mathrm{M}$ (all from Sigma-Aldrich, St. Louis, MO, USA) were added directly to the buffer, and the samples were incubated for $20 \mathrm{~min}$ at $37^{\circ} \mathrm{C}$. After incubation, the cells were washed twice with ice-cold PBS. Fluorescence was measured using an Accuri C6 flow cytometer (BD Bioscience, San Jose, CA, USA). Details about the measurements are described elsewhere $[17,20]$. Only viable cells that were not stained with propidium iodide were evaluated. The proportion of dead cells that were stained with PI never exceeded 5\%.

\subsection{Monitoring of Cell Cycle Progression}

$\mathrm{S}, \mathrm{R}$, and T cells $\left(10^{6}\right.$ cells per $\left.\mathrm{ml}\right)$ were cultured for 4,8 , and $24 \mathrm{~h}$ with or without $5 \mathrm{nM}$ BOR under standard culture conditions. The cells were washed with PBS and then fixed for $1 \mathrm{~h}$ in ice-cold $70 \%(v / v)$ ethanol. In samples of these cells, RNA was eliminated 
by incubation with RNase A (Thermo Fisher Scientific, Waltham, MA, USA) for 30 min at $37^{\circ} \mathrm{C}$, and then, the cellular DNA content was visualized with PI staining. The samples were analyzed by flow cytometry using an Accuri C6 flow cytometer. To exclude doublets, the doublet discrimination mode was used by evaluating the PI fluorescence signal by peak width (FL2-W) and area (FL2-A).

\subsection{Detection of Gene Expression by qRT-PCR}

Total mRNA was isolated from $S, \mathrm{R}$, and T cells using TRI reagent (Molecular Research Center, Inc. Cincinnati, OH, USA) according to the manufacturer's instructions. Two micrograms of DNAse I (Thermo Fisher Scientific, Bremen, Germany) was used to remove DNA from each sample. The total RNA in the samples thus treated was subjected to reverse transcription using the RevertAid-H Minus cDNA certified synthesis kit (Thermo Fisher Scientific, Bremen, Germany) according to the manufacturer's protocol. Primers (the sequences and sizes of PCR products are summarized in Table 1) and cDNA samples were prepared for qPCR with iTaq Universal SYBR Green Super Mix (Bio-Rad Laboratories, Philadelphia, PA, USA). For PCR, the CFX96 Real-Time System C1000 Touch Thermal Cycler (Bio-Rad, Laboratories, USA) was used either for initial denaturation at $95{ }^{\circ} \mathrm{C}$ for $10 \mathrm{~min}$ or for 39 cycles at $95{ }^{\circ} \mathrm{C}$ for $15 \mathrm{~s}$ and at $59{ }^{\circ} \mathrm{C}$ for $30 \mathrm{~s}$. The relative amount of each transcript was calculated by a standard curve generated from cycle thresholds for the cDNA samples and normalized to the amount of $\beta$-actin. Polymerase chain reaction (PCR) was performed in triplicate for each sample, and all experiments were repeated twice. Significance was established by unpaired Student's $t$-test. The data were analyzed with Bio-Rad CFX96T software. Baseline levels for each gene were computed automatically. The results were quantified relative to the cycle threshold value according to the formula $\Delta \Delta \mathrm{Ct}=\Delta$ Ctsample $-\Delta$ Cthousekeeper.

Table 1. The primer sequences.

\begin{tabular}{|c|c|c|c|}
\hline Gene & Forward Primer & Revers Primer & bp \\
\hline Actb & 5'-TCG CCA TGG ATG ACG ATA-3' & 5'-CAC GAT GGA GGG GAA TAC AG-3' & 110 \\
\hline Human $A B C B 1$ & $5^{\prime}$-GCA ATG GAG GAG CAA AGA AG-3' & $5^{\prime}$-CCA AAG TTC CCA CCA CCA TA-3' & 150 \\
\hline Mouse $A b c b 1$ & $5^{\prime}$-TGG GAA CTC TGG CTG CTA TT-3' & $5^{\prime}$-GGC GTA CGT GGT CAT TTC TT-3' & 179 \\
\hline$A b c c 1$ & $5^{\prime}$-ACC AGC AAC CCC GAC TTT AC-3' & $5^{\prime}$-TGG TTT TGT TGA GGT GTG TCA-3' & 151 \\
\hline$A b c g 2$ & $5^{\prime}$-CCA CGT GTT AGT ACC AAT GTC G-3' & $5^{\prime}$-TTT CCG GAC TAG AAA CCC ACT-3' & 151 \\
\hline Psmb1 & 5'-CGA GAT AGC CCC AAA TGC TA-3' & 5'-AAG AAG CGC CGT GAG TAC AG-3' & 194 \\
\hline Psmb2 & 5'-GTC ACC CCC AGC TCA GTC-3' & $5^{\prime}$-GGA AGC GAC GAG GAC ATA GT-3' & 153 \\
\hline Psmb5 & $5^{\prime}$-GCC ATC TAC CAA GCC ACC TA-3' & 5'-TAG CCA TGG AGA CCC ACC TA-3' & 193 \\
\hline Psma7 & $5^{\prime}$-GTT GGT GTT CGA GGA AAG GA-3' & $5^{\prime}$-GTC ACT GGG TCC TCC ACT GT-3' & 212 \\
\hline Usp7 & 5'-AGC AAC GCA GAA GAG GAC AT-3' & 5'-TTT GGT GTG GTC TGT CTG GA-3' & 181 \\
\hline Usp28 & $5^{\prime}$-CCA GTC ACG ACA CAA CTG CT- $3^{\prime}$ & $5^{\prime}$-TCC AGG AGA CTC AAG GCA AT-3' & 139 \\
\hline Usp 48 & $5^{\prime}$-GAT CCA TGG GGG AAA AGA TT-3' & $5^{\prime}$-TGC TGC TGC CCA GTA TCT AA- $3^{\prime}$ & 144 \\
\hline Usp1 & $5^{\prime}$-AAG GGA AGC TGC AAA GAA GA-3' & $5^{\prime}$-GCC TTG GCT GTG TAG CAA GT-3' & 145 \\
\hline Usp2 & 5'-GTG GTG AGC CCA TCT GAG TT-3' & $5^{\prime}$-GTG GAG ACC ATC CAG AAG GA-3' & 114 \\
\hline Uchl5 & 5'-TGG TCC AGG ACT CCA GAC TT-3' & $5^{\prime}$-TGC ACA TCT TGA TGC GTA CA-3' & 115 \\
\hline p15 & $5^{\prime}$-AGG ACG CTC ACC GAA GCT A-3' & $5^{\prime}$-CTG TGG CAG AAA TGG TCC TT-3' & 100 \\
\hline$p 16$ & 5'-CAA CGT TCA CGT AGC AGC TC-3' & 5'-ACC AGC GTG TCC AGG AAG-3' & 120 \\
\hline$p 27$ & $5^{\prime}$-AGT CAG CGC AAG TGG AAT TT-3' & $5^{\prime}$-AGT AGA ACT CGG GCA AGC TG-3' & 100 \\
\hline$p 21 t 1$ & 5'-TCC ACA GCG ATA TCC AGA CA-3' & 5'-ATG AGC GCA TCG CAA TCA C-3' & 148 \\
\hline$p 21 t 2$ & $5^{\prime}$-TTA AGG ACG TCC CAC TTT GC-3' & $5^{\prime}$-AGA CAA CGG CAC ACT TTG CT-3' & 107 \\
\hline$C y c B 1$ & $5^{\prime}$-GGT GAC TTC GCC TTT GTG AC-3' & $5^{\prime}$-CTA CGG AGG AAG TGC AGA GG-3' & 125 \\
\hline$C y c D 1$ & $5^{\prime}$-AGC AGA AGT GCG AAG AGG AG-3' & $5^{\prime}$-CAA GGG AAT GGT CTC CTT CA-3' & 149 \\
\hline CycE1 & $5^{\prime}$-GGA AAA TCA GAC CAC CCA GA-3' & 5'-AGG ATG ACG CTG CAG AAA GT-3' & 131 \\
\hline$C y c A 1$ & $5^{\prime}$-ACA CAG ACC CAA GGC TCA CT-3' & 5'-ACA GGG TCT CTG TGC GAA GT-3' & 122 \\
\hline$C d k 2$ & $5^{\prime}$-CAT TCC ТCT ТCC CСТ СAT CA-3' & $5^{\prime}$-TAA GCA GGT TCT GGG GCT TA-3' & 110 \\
\hline$C d k 4$ & $5^{\prime}$-TAT GAA CCC GTG GCT GAA AT-3' & $5^{\prime}$-TCC AGC TGC TCC TCC ATT AG-3' & 123 \\
\hline$C d k 6$ & $5^{\prime}$-AGA AGG TCG GTC CGT CTA GC-3' & $5^{\prime}$-ACT CAG GCT GTC CTT CTC CA-3' & 132 \\
\hline$C d k 1$ & $5^{\prime}$-TTG AAA GCG AGG AAG AAG GA-3' & 5'-TCC ATG GAC AGG AAC TCA AA-3' & 148 \\
\hline Hsp90aa & $5^{\prime}$-GGG AGC TCA TCT CCA ATT CA-3' & 5'-ATT GAT GTG CAG CTC CTT CC-3' & 101 \\
\hline Hsp90ab & $5^{\prime}$-GAT TGT CAC CTT TTC AAC CTT CTT- ${ }^{\prime}$ & $5^{\prime}$-TGA CCT CCT TGT CAG AGT ATG TGT-3' & 344 \\
\hline
\end{tabular}




\subsection{Western Blotting}

The cell protein contents were determined by Western blotting using the following protocol: Cells were washed in PBS and then lysed by SoluLyse reagent with protease inhibitor cocktail (from Sigma-Aldrich, St. Louis, MO, USA) according to the manufacturer's protocol. Protein lysates were applied to electrophoresis gels ( $30 \mu \mathrm{g}$ per lane) and then separated by SDS-PAGE using a Mini-PROTEAN ${ }^{\circledR}$ Electrophoresis System (Bio-Rad Laboratories, Philadelphia, PA, USA). The proteins were transferred by electroblotting to PVDF membranes (GE Healthcare Europe GmbH, Vienna, Austria). Protein bands were detected using specific primary antibodies against Hsp90 $\alpha$ and HSP90 $\alpha \beta$ and GAPDH (all obtained from Santa Cruz Biotechnology, Dallas, TX, USA), Hsp90ß, the $26 \mathrm{~S}$ proteasome, polyubiquitinated proteins with K63 linkage, and polyubiquitinated proteins with K48 linkage (all obtained from Abcam Cambridge, United Kingdom). Anti-mouse/anti-rabbit antibodies conjugated with horseradish peroxidase (obtained from Santa Cruz Biotechnology, Dallas, TX, USA) were used as secondary antibodies. The protein bands were visualized with an ECL detection system (GE Healthcare Europe GmbH, Vienna, Austria) using an Amersham Imager 600 (GE Healthcare Europe GmbH, Vienna, Austria). Broadrange protein molecular weight markers (Thermo Fisher Scientific, Bremen, Germany) were used for molecular weight estimations. The optical density of the protein bands was quantified by densitometry using ImageAmersham ${ }^{\mathrm{TM}}$ image analysis software (GE Healthcare Europe $\mathrm{GmbH}$, Vienna, Austria). All estimations were performed in triplicate, and the optical densities were normalized to GAPDH as an internal standard. Significance was established by unpaired Student's $t$-test.

\subsection{Visualization of HSP90 $\alpha$-and $\beta$-Immunoreactive Proteins in $S, R$, and T Cells by Immunofluorescence Confocal Microscopy}

After culturing, the cells were washed and resuspended in PBS, and then, the cells were transferred to poly-L-lysine slides (Menzel Glaser, (Thermo Fisher Scientific, Bremen, Germany). Slide-bound cells were washed twice in PBS and then fixed with $1 \%$ paraformaldehyde in PBS for $10 \mathrm{~min}$. After fixation, the cells were permeabilized with $0.1 \%$ Triton-X 100 in PBS, washed in PBS, and blocked with $1 \%$ BSA in PBS for $1 \mathrm{~h}$ at $4{ }^{\circ} \mathrm{C}$. The cells were then incubated with specific antibodies against both HSP $90 \alpha$ and HSP $90 \beta$ (described in Section 4.6) for $1 \mathrm{~h}$ at $4{ }^{\circ} \mathrm{C}$ in PBS containing 1\% BSA. The cells were washed twice in PBS containing 1\% BSA, and donkey anti-rabbit antibody linked with Alexa Fluor 488 (Life Technologies Corporation, Wilsonville, OR, USA) in PBS containing 1\% BSA was applied to the cells and incubated for $1 \mathrm{~h}$ at $4{ }^{\circ} \mathrm{C}$. The samples were washed twice in PBS containing $1 \%$ BSA, and the cells were then additionally labeled with $10 \mathrm{mg} / \mathrm{L}$ of 4'-6-diamidino-2-phenylindole (DAPI, Sigma-Aldrich, St. Louis, MO, USA) in PBS for nuclei visualization. Finally, coverslips were mounted on slides with mounting medium ( $80 \%$ glycerol), and the samples were observed using a Leica TCS SP8 AOBS confocal microscope (Leica Microsystems, Wetzlar, Germany).

\subsection{Immunoprecipitation of the $26 S$ Proteasome and HSP90 $\alpha$ or HSP9O $\beta$}

L1210 cell variants were incubated with or without $5 \mathrm{nM}$ BOR for $24 \mathrm{~h}$. Subsequently, cells were harvested, and whole cell lysates were prepared by homogenization in SoluLyse as described in Section 4.6. The isolated proteins were used for immunoprecipitation according to the following protocol. Proteins ( $60 \mu \mathrm{g}$, determined by Lowry assay) were dissolved to a final volume of $300 \mu \mathrm{L}$ using $50 \mathrm{mM}$ Tris- $\mathrm{HCl}$ ( $\mathrm{pH}$ 7.0) containing antibodies against either the $26 \mathrm{~S}$ proteasome or HSP90 $\alpha$ (described in Section 4.6). After $2 \mathrm{~h}$ of incubation at $4{ }^{\circ} \mathrm{C}, 20 \mu \mathrm{L}$ of protein A/G PLUS-agarose (Santa Cruz Biotechnology, Dallas, TX, USA) was added, and the mixture was incubated overnight at $4{ }^{\circ} \mathrm{C}$. The agarose was then pelleted by centrifugation $(10 \mathrm{~min}$ at $10,000 \mathrm{rpm})$ at $4{ }^{\circ} \mathrm{C}$ and washed twice with $50 \mathrm{mM}$ Tris-HCl buffer. The agarose-bound proteins were solubilized directly in SDS-PAGE sample buffer, loaded onto a $10 \%$ gel, and electrophoretically separated. The proteins were then electroblotted onto a PVDF membrane, and the presence of $26 \mathrm{~S}$ proteasome, $\mathrm{HSP} 90 \alpha$, 
and HSP90 $\beta$ in the immunoprecipitate was detected using the primary and secondary antibodies described in Section 4.4. A rabbit IgG light chain secondary signal was used as an internal standard.

\subsection{Proteasome Activity Assay}

The proteasome activity assay was performed with $2 \times 10^{6}$ cells per well. All variants of L1210 cells were cultivated either for $4 \mathrm{~h}$ in the absence or presence of $5 \mathrm{nM}$ BOR or $1 \mu \mathrm{M}$ AADG (17-N-allylamino-17-demethoxygeldanamycin, Sigma-Aldrich, St. Louis, MO, USA, an inhibitor of HSP90) in cultivation medium for $24 \mathrm{~h}$. Proteasome activity in the samples was measured using an ab107921 kit (Abcam Cambridge, United Kingdom) according to the manufacturer's instructions. All details of the assay were described previously [25].

\subsection{Statistical Analysis and Data Processing}

Numerical data are expressed as the mean \pm SD of three independent measurements. Statistical significance was assessed using an unpaired Student's $t$-test using SigmaPlot 8.0 software (Systat Software, Inc., San Jose, CA, USA).

Line dependences were subjected to linear regression and were characterized by a 95\% confidence interval using SigmaPlot.

Dose-response curves were fitted by the function of exponential decay (Equation (1) [25]) by nonlinear regression using SigmaPlot.

$$
\mathrm{N}=\mathrm{N}_{\mathrm{O}} \times \mathrm{e}^{\left[\ln (0.5) \times\left(\frac{\mathrm{c}}{\mathrm{IC}}\right)\right]}
$$

where $\mathrm{N}$ represents the MTT signal in the presence of the respective substances at concentration $\mathrm{c}$ and $\mathrm{N}_{\mathrm{O}}$ represents the MTT signal in the absence of any substance. $\mathrm{IC}_{50}$ is the mean lethal concentration of substances when $\mathrm{N}=0.5 \times \mathrm{N} 0$.

\section{Conclusions}

Variants of P-gp-positive mouse L1210 leukemia cells, $\mathrm{R}$ and T cells, are sensitive to $\mathrm{BOR}$ at nanomolar concentrations, similar to their P-gp-negative $\mathrm{S}$ cell counterparts. P-gp transport activity does not appear to limit the effect of BOR on R or T cells. However, we found various changes between the $R$ and $T$ cells on the one hand and $S$ cells on the other hand that could protect P-gp-positive cells from the effect of BOR. These changes (summarized on Figure 10) include differences in cell cycle progression between P-gppositive and P-gp-negative cells. BOR induced less pronounced G2/M phase cell cycle arrest in the $\mathrm{R}$ and $\mathrm{T}$ cells than in the $\mathrm{S}$ cells. These features are associated with altered expression levels of genes encoding CDKs, their activating cyclins, and/or their protein inhibitors in the $\mathrm{R}$ and $\mathrm{T}$ cells compared to $\mathrm{S}$ cells.

When comparing P-gp-positive $\mathrm{R}$ and $\mathrm{T}$ cells with $\mathrm{P}$-gp-negative $\mathrm{S}$ cells, altered expression levels are observed in deubiquitinases, 26S proteasome subunits or HSP90. After incubating the cells with BOR and subsequent removal of BOR by extensive washing, the proteasome activity in the $\mathrm{S}$ cells is reduced more than in the $\mathrm{R}$ or T cells. However, these changes, although statistically significant, are not sufficient to alter the overall sensitivity of the cells to BOR. 


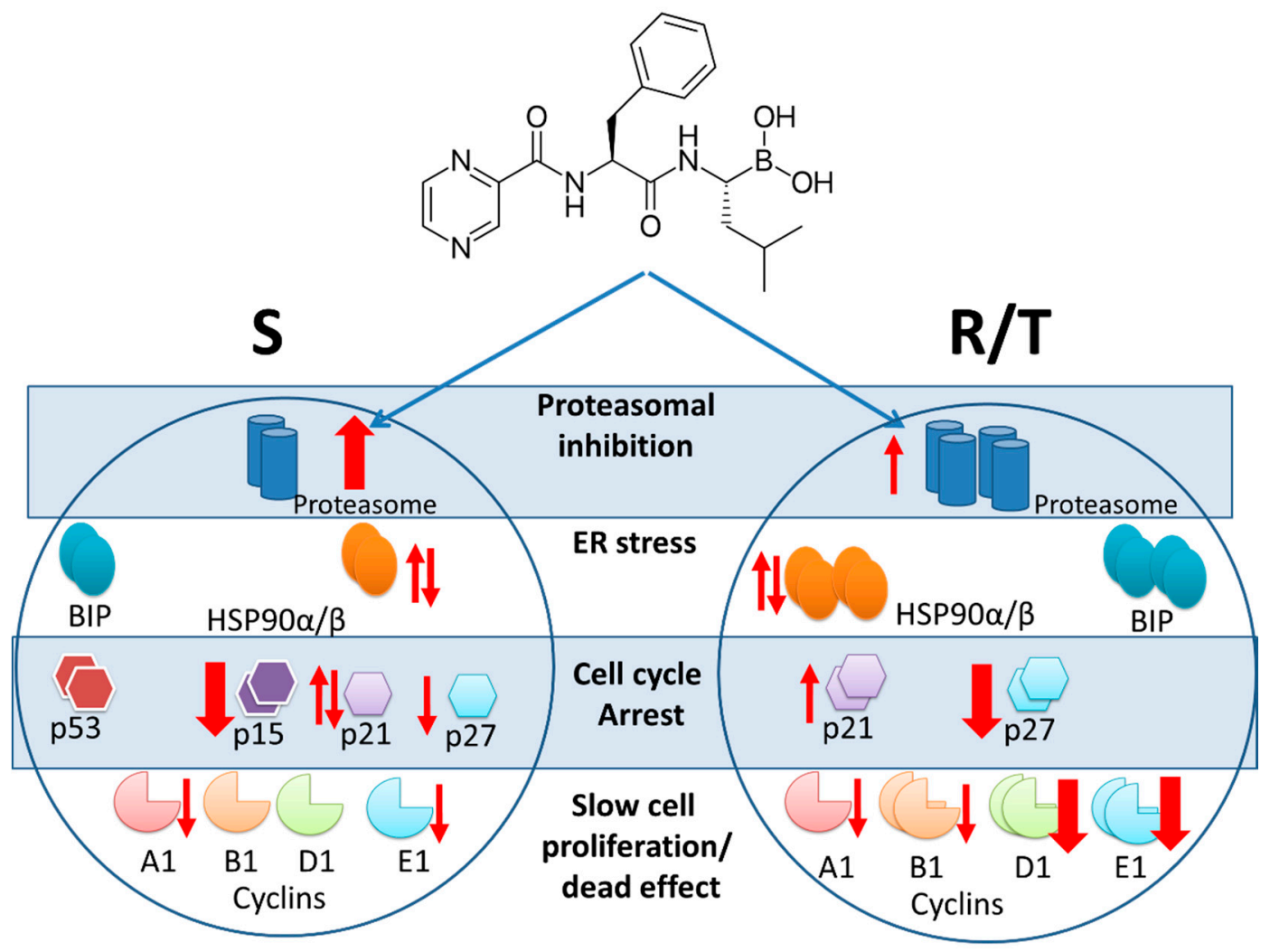

Figure 10. Scheme of the effect of bortezomib on $S, R$, and T cells. P-gp positive R and T cells have increased expression levels of the proteasome subunits, $\mathrm{HSP} 90 \alpha / \beta$, p21, and p27 and cyclins B1, D1, and E1 as P-gp negative S cells. In contrast, p15 expression is observed in S cells only. In addition, there is significantly more proapotically acting p53 in S cells, which is found in small amounts in R and T cells [61]. In contrast, $\mathrm{R}$ and T cells have higher levels of GRP78/BIP, which is a blocker of endoplasmic reticulum stress receptors [13]. These characteristics are responsible for the differences in proliferation between $S$ cells on the one hand and $\mathrm{R}$ and $\mathrm{T}$ cells on the other hand. They also explain the lower apoptotic response of $\mathrm{R}$ and $\mathrm{T}$ cells to toxic stress [22] or to endoplasmic reticulum stress [13]. Bortezomib administered at a concentration of $5 \mathrm{nM}$ causes a strong increase in the expression of proteasome subunits and a strong decrease in p15 expression in $\mathrm{S}$ cells over $24 \mathrm{~h}$. The expression of cyclins A1 and E1 as well as p27 decreases less intensively in these cell variants and we did not show a clear trend with HSP90 $\alpha / \beta$ and p21 protein. In contrast, the expression of cyclins D1 and E1 as well as the p27 protein decreases strongly in $\mathrm{R}$ and $\mathrm{T}$ cells during $24 \mathrm{~h}$ after botezomib administration. A slight decrease in expression of cyclins A1 and B1 and, conversely, a slight increase in p21 protein and proteasome subunits was observed in these cell variants. As in $S$ cells, we did not observe a clear trend in $\mathrm{HSP} 90 \alpha / \beta$ and p21 expressions in R and T cells. The changes induced by botezomib treatment in P-gp-negative $S$ cells and P-gp-positive $\mathrm{R}$ and $\mathrm{T}$ cells appear to attenuate differences in the original observed characteristics present before treatment.

Supplementary Materials: The following are available online at https:/ / www.mdpi.com/article/10 .3390/ijms22115504/s1, Table S1: Characterization of S, R and T variants of L1210 cells. Figure S1: Structures of bortezomib-proteasome inhibitor, 17-(allylamino)-17-demethoxy-geldanamycinHSP90 inhibitor, Suc-LLVY-AMC — Proteasome substrate and MG-132 proteasome inhibitor. Figure S2: Effect of bortezomib and vincristine on the viability of S, R and T variants of L1210 cells. Figure S3: Effect of bortezomib on expression of MRP1 and BCRP in S, R and T cells. Figure S4: Histograms of the fluorescence cytometry analysis used to detect cell cycle progression based on quantification of cellular DNA stained with propidium iodide. Figure S5: Expression of the Cdkn1a gene encoding the p21 protein in S, R and T cells. Figure S6: Immunodetection of HSP90 by an antibody against both HSP90 $\alpha$ and HSP90ß. Figure S7: Measurements of 26S proteasome activity with an ab107921 kit.

Author Contributions: Conceptualization, L.P., A.B., Z.S. and M.Š.; funding acquisition, M.Š., V.B., A.B. and Z.S.; data curation, T.K., L.P., A.M., A.P., V.B. and M.Š.; supervision, A.B., Z.S. and M.Š.; investigation, T.K., L.P., A.M., A.P., V.B. and M.Š.; methodology, L.P., M.Š., A.B. and Z.S.; writing- 
original draft preparation, T.K., L.P. and M.Š.; project administration, V.B.; writing-review and editing, A.B. and Z.S. All authors have read and agreed to the published version of the manuscript.

Funding: This research was funded by the Slovak Agency for Research and Development (grants APVV-19-0093 and APVV-19-0094) and the Grant Agency of the Ministry of Education of the Slovak Republic and the Slovak Academy of Sciences (grants VEGA 2/0157/18, VEGA 2/0070/19, VEGA 2/0159/19 and VEGA 2/0171/21). Tomas Kyca is supported by the Slovak Academy of Sciences in the grant scheme: Grant Program for Doctoral Students of the Slovak Academy of Sciences; Grant number: APP0011.

Institutional Review Board Statement: Not applicable.

Informed Consent Statement: Not applicable.

Data Availability Statement: Additional data as well as resistant variants of L1210 cells are available from the authors.

Conflicts of Interest: The authors declare no conflict of interest.

\section{Abbreviations}

\begin{tabular}{|c|c|}
\hline $19 S$ & Regulatory cap of proteasome \\
\hline $20 \mathrm{~S}$ & Catalytic core of proteasome \\
\hline $26 S$ & Completed proteasome \\
\hline AADG & 17-(allylamino)-17-demethoxygeldanamycin \\
\hline $\mathrm{ABC}$ & ATP-binding cassette \\
\hline ABCB1 & $\mathrm{B} 1$ member of $\mathrm{ABC}$ transporter family, P-gp \\
\hline $\mathrm{ABCC} 1$ & $\mathrm{C} 1$ member of $\mathrm{ABC}$ transporter family, MRP1 \\
\hline $\mathrm{ABCC} / \mathrm{ABCG}$ & $\mathrm{C}$ and $\mathrm{G}$ subfamily of $\mathrm{ABC}$ transporter \\
\hline Akt & Serine/threonine specific protein kinase B (PKB) \\
\hline ALL & Acute lymphoblastic leukemia \\
\hline AMC & 7-amino-4-methylcoumarin \\
\hline ATP & Adenosine triphosphate \\
\hline $\mathrm{BiP}$ & Binding immunoglobulin protein \\
\hline BOR & Bortezomib \\
\hline BSA & Bovine serum albumin \\
\hline Calcein/AM & Acetoxymethyl-calcein \\
\hline $\mathrm{CC}$ & Cell cycle \\
\hline Ccna1, b1,d1,e1 & Mouse gene encoding cyclin A1, B1, D1, and E1, respectively \\
\hline $\mathrm{CDK}(\mathrm{s})$ & Cyclin-dependent kinase(s) \\
\hline$C d k 1,2,4,6$ & Mouse gene encoding CDK1, 2, 4, and 6, respectively \\
\hline CDK1, 2, 4, 6 & Cyclin-dependent kinase $1,2,4$, and 6 , respectively \\
\hline CIP & CDK-interacting protein, inhibitor of CDK \\
\hline CKIs & Cyclin-dependent kinase inhibitors \\
\hline DAPI & $4^{\prime}$,6-diamidino-2-phenylindole, fluorescent stain \\
\hline DSMZ & German Collection of Microorganisms and Cell Culture \\
\hline ECL & Enhanced chemiluminescence \\
\hline EMA & European medicines agency \\
\hline ER & Endoplasmic reticulum \\
\hline FAV & Fluorescein isothiocyanate labeled annexin $\mathrm{V}$ \\
\hline FDA & U.S. Food and Drug Administration \\
\hline GAPDH & Glyceraldehyde 3-phosphate dehydrogenase \\
\hline GRP78 & Glucose-regulated protein 78-kda (bip) \\
\hline HSP90 & Heat shock protein 90 \\
\hline Hsp90aa, ab & Mouse gene encoding $\mathrm{HSP} 90 \alpha$ and $\beta$, respectively \\
\hline $\mathrm{HSP} 90 \alpha, \beta$ & Heat shock protein $90 \alpha$ and $\beta$, respectively \\
\hline IC50 & Half maximal inhibitory concentration \\
\hline IgG & Immunoglobulin $\mathrm{G}$ \\
\hline INK4 & Inhibitor of CDK4 \\
\hline K48 & Lysine 48 \\
\hline K63 & Lysine 63 \\
\hline
\end{tabular}




\begin{tabular}{|c|c|}
\hline KIP & Kinase inhibitory protein, inhibitor of CDK \\
\hline L1210 & Mouse lymphocytic leukemia cell line \\
\hline MDR & Multidrug resistance \\
\hline MG-132 & Inhibitor of proteasome \\
\hline MTT & Methylthiazolyldiphenyl-tetrazolium bromide \\
\hline $\mathrm{p} 15,16$ & CDK4/6-inhibitors known also as INK4 \\
\hline $\mathrm{p} 21,27,57$ & CDK-interacting protein/kinase inhibitory protein (CIP/KIP) \\
\hline PAGE & Polyacrylamide gel electrophoresis \\
\hline PBS & Phosphate buffered saline \\
\hline PCR & Polymerase chain reaction \\
\hline PFD & Paraformaldehyde \\
\hline P-gp & P-glycoprotein \\
\hline PI & Propidium iodide \\
\hline PNCA & Proliferating cell nuclear antigen \\
\hline Psma7 & Mouse gene encoding proteasome subunit $\alpha 7$ \\
\hline Psmb1, b2, b5 & Mouse gene encoding proteasome $\beta 1, \beta 2$, and $\beta 5$, respectively \\
\hline PVDF & Polyvinylidene fluoride, special plastic \\
\hline qRT-PCR & Quantitative reverse transcription-polymerase chain reaction \\
\hline $\mathrm{R}$ & P-gp positive L1210 cells obtained by selectin with VCR \\
\hline RPMI 1640 & Roswell Park Memorial Institute 1640 medium \\
\hline S & Parental L1210cells \\
\hline SDS & Sodium dodecyl sulfate \\
\hline $\mathrm{T}$ & P-gp positive L1210 cells obtained by transfection with P-gp \\
\hline TRAF2 & Tumor necrosis factor receptor-associated factor 2 \\
\hline Ubi & Ubiquitin \\
\hline UPR & Unfolded protein response \\
\hline UCHL5 & Ubiquitin C-Terminal Hydrolase L5 \\
\hline USP1 & Ubiquitin-specific protease 1 \\
\hline USP2 & Ubiquitin-specific protease 2 \\
\hline USP28 & Ubiquitin-specific protease 28 \\
\hline USP48 & Ubiquitin-specific protease 48 \\
\hline USP7 & Ubiquitin-specific protease 7 \\
\hline VCR & Vincristine \\
\hline YB-1 & Y box binding protein 1 \\
\hline
\end{tabular}

\section{References}

1. Kazandjian, D.; Blumenthal, G.M.; Yuan, W.; He, K.; Keegan, P.; Pazdur, R. Fda approval of gefitinib for the treatment of patients with metastatic egfr mutation-positive non-small cell lung cancer. Clin. Cancer Res. 2016, 22, 1307-1312. [CrossRef]

2. Ema Bortezomib Drug Label (Epar Poduct Information). Available online: Http://www.Ema.Europa.Eu/docs/en_gb/document_ library /epar_-_product_information/human/000539/wc500048471.Pdf (accessed on 21 March 2021).

3. Terpos, E.; Katodritou, E.; de la Rubia, J.; Hungria, V.; Hulin, C.; Roussou, M.; Delforge, M.; Bries, G.; Stoppa, A.M.; Aagesen, J.; et al. Bortezomib-based therapy for relapsed/refractory multiple myeloma in real-world medical practice. Eur. J. Haematol. 2018, 101, 556-565. [CrossRef] [PubMed]

4. Robak, P.; Robak, T. Bortezomib for the treatment of hematologic malignancies: 15 years later. Drugs RED 2019, $19,73-92$.

5. Bonvini, P.; Zorzi, E.; Basso, G.; Rosolen, A. Bortezomib-mediated 26s proteasome inhibition causes cell-cycle arrest and induces apoptosis in cd-30+ anaplastic large cell lymphoma. Leukemia 2007, 21, 838-842. [CrossRef] [PubMed]

6. Bolognese, A.; Esposito, A.; Manfra, M.; Catalano, L.; Petruzziello, F.; Martorelli, M.C.; Pagliuca, R.; Mazzarelli, V.; Ottiero, M.; Scalfaro, M.; et al. An nmr study of the bortezomib degradation under clinical use conditions. Adv. Hematol. 2009, $2009,704928$. [CrossRef]

7. Bruning, A.; Burger, P.; Vogel, M.; Rahmeh, M.; Friese, K.; Lenhard, M.; Burges, A. Bortezomib treatment of ovarian cancer cells mediates endoplasmic reticulum stress, cell cycle arrest, and apoptosis. Investig. New Drugs 2009, 27, 543-551. [CrossRef]

8. Bertaina, A.; Vinti, L.; Strocchio, L.; Gaspari, S.; Caruso, R.; Algeri, M.; Coletti, V.; Gurnari, C.; Romano, M.; Cefalo, M.G.; et al. The combination of bortezomib with chemotherapy to treat relapsed/refractory acute lymphoblastic leukaemia of childhood. Br. J. Haematol. 2017, 176, 629-636. [CrossRef] 
9. Messinger, Y.H.; Gaynon, P.S.; Sposto, R.; van der Giessen, J.; Eckroth, E.; Malvar, J.; Bostrom, B.C.; Therapeutic Advances in Childhood, L.; Lymphoma, C. Bortezomib with chemotherapy is highly active in advanced b-precursor acute lymphoblastic leukemia: Therapeutic advances in childhood leukemia \& lymphoma (tacl) study. Blood 2012, 120, 285-290. [PubMed]

10. O'Connor, R.; Ooi, M.G.; Meiller, J.; Jakubikova, J.; Klippel, S.; Delmore, J.; Richardson, P.; Anderson, K.; Clynes, M.; Mitsiades, C.S.; et al. The interaction of bortezomib with multidrug transporters: Implications for therapeutic applications in advanced multiple myeloma and other neoplasias. Cancer Chemother. Pharmacol. 2013, 71, 1357. [CrossRef]

11. Panischeva, L.A.; Kakpakova, E.S.; Rybalkina, E.Y.; Stavrovskaya, A.A. Influence of proteasome inhibitor bortezomib on the expression of multidrug resistance genes and akt kinase activity. Biochemistry 2011, 76, 1009-1016. [CrossRef]

12. Mynott, R.L.; Wallington-Beddoe, C.T. Inhibition of p-glycoprotein does not increase the efficacy of proteasome inhibitors in multiple myeloma cells. ACS Pharmacol. Transl. Sci. 2021, 4, 713-729. [CrossRef]

13. Seres, M.; Pavlikova, L.; Bohacova, V.; Kyca, T.; Borovska, I.; Lakatos, B.; Breier, A.; Sulova, Z. Overexpression of grp78/bip in p-glycoprotein-positive 11210 cells is responsible for altered response of cells to tunicamycin as a stressor of the endoplasmic reticulum. Cells 2020, 9, 890. [CrossRef]

14. Takahashi, K.; Inukai, T.; Imamura, T.; Yano, M.; Tomoyasu, C.; Lucas, D.M.; Nemoto, A.; Sato, H.; Huang, M.; Abe, M.; et al. Anti-leukemic activity of bortezomib and carfilzomib on b-cell precursor all cell lines. PLoS ONE 2017, 12, e0188680.

15. Uhrik, B.; Tribulova, N.; Klobusicka, M.; Barancik, M.; Breier, A. Characterization of morphological and histochemical changes induced by overexpression of p-glycoprotein in mouse leukemic cell line 11210. Neoplasma 1994, 41, 83-88.

16. Polekova, L.; Barancik, M.; Mrazova, T.; Pirker, R.; Wallner, J.; Sulova, Z.; Breier, A. Adaptation of mouse leukemia cells 11210 to vincristine. Evidence for expression of p-glycoprotein. Neoplasma 1992, 39, 73-77.

17. Sulova, Z.; Ditte, P.; Kurucova, T.; Polakova, E.; Rogozanova, K.; Gibalova, L.; Seres, M.; Skvarkova, L.; Sedlak, J.; Pastorek, J.; et al. The presence of p-glycoprotein in 11210 cells directly induces down-regulation of cell surface saccharide targets of concanavalin A. Anticancer Res. 2010, 30, 3661-3668.

18. Gibalova, L.; Seres, M.; Rusnak, A.; Ditte, P.; Labudova, M.; Uhrik, B.; Pastorek, J.; Sedlak, J.; Breier, A.; Sulova, Z. P-glycoprotein depresses cisplatin sensitivity in 11210 cells by inhibiting cisplatin-induced caspase-3 activation. Toxicol. In Vitro 2012, 26, 435-444. [CrossRef]

19. Pavlikova, L.; Seres, M.; Hano, M.; Bohacova, V.; Sevcikova, I.; Kyca, T.; Breier, A.; Sulova, Z. L1210 cells overexpressing abcb1 drug transporters are resistant to inhibitors of the $\mathrm{n}$ - and o-glycosylation of proteins. Molecules 2017, 22, 1104. [CrossRef]

20. Seres, M.; Cholujova, D.; Bubencikova, T.; Breier, A.; Sulova, Z. Tunicamycin depresses p-glycoprotein glycosylation without an effect on its membrane localization and drug efflux activity in 11210 cells. Int. J. Mol. Sci. 2011, 12, 7772-7784. [CrossRef]

21. Seres, M.; Polakova, E.; Krizanova, O.; Hudecova, S.; Klymenko, S.V.; Breier, A.; Sulova, Z. Overexpression of p-glycoprotein in $11210 / \mathrm{vcr}$ cells is associated with changes in several endoplasmic reticulum proteins that may be partially responsible for the lack of thapsigargin sensitivity. Gen. Physiol. Biophys. 2008, 27, 211-221.

22. Breier, A.; Gibalova, L.; Seres, M.; Barancik, M.; Sulova, Z. New insight into p-glycoprotein as a drug target. Anticancer Agents Med. Chem. 2013, 13, 159-170. [CrossRef]

23. Hano, M.; Tomasova, L.; Seres, M.; Pavlikova, L.; Breier, A.; Sulova, Z. Interplay between p-glycoprotein expression and resistance to endoplasmic reticulum stressors. Molecules 2018, 23, 337. [CrossRef]

24. Iurlaro, R.; Munoz-Pinedo, C. Cell death induced by endoplasmic reticulum stress. FEBS J. 2016, 283, 2640-2652. [CrossRef]

25. Cagala, M.; Pavlikova, L.; Seres, M.; Kadlecikova, K.; Breier, A.; Sulova, Z. Development of resistance to endoplasmic reticulum stress-inducing agents in mouse leukemic 11210 cells. Molecules 2020, 25, 2517. [CrossRef]

26. Minderman, H.; Zhou, Y.; O'Loughlin, K.L.; Baer, M.R. Bortezomib activity and in vitro interactions with anthracyclines and cytarabine in acute myeloid leukemia cells are independent of multidrug resistance mechanisms and p53 status. Cancer Chemother. Pharmacol. 2007, 60, 245-255. [CrossRef]

27. Volk, E.L.; Farley, K.M.; Wu, Y.; Li, F.; Robey, R.W.; Schneider, E. Overexpression of wild-type breast cancer resistance protein mediates methotrexate resistance. Cancer Res. 2002, 62, 5035-5040.

28. Winter, S.S.; Ricci, J.; Luo, L.; Lovato, D.M.; Khawaja, H.M.; Serna-Gallegos, T.; Debassige, N.; Larson, R.S. Atp binding cassette c1 (abcc1/mrp1)-mediated drug efflux contributes to disease progression in t-lineage acute lymphoblastic leukemia. Health 2013, 5, 41. [CrossRef]

29. Elefantova, K.; Lakatos, B.; Kubickova, J.; Sulova, Z.; Breier, A. Detection of the mitochondrial membrane potential by the cationic dye jc-1 in 11210 cells with massive overexpression of the plasma membrane abcb1 drug transporter. Int. J. Mol. Sci. 2018, 19, 1985. [CrossRef]

30. Pozarowski, P.; Darzynkiewicz, Z. Analysis of cell cycle by flow cytometry. Methods Mol. Biol. 2004, 281, 301-311.

31. Ding, L.; Cao, J.; Lin, W.; Chen, H.; Xiong, X.; Ao, H.; Yu, M.; Lin, J.; Cui, Q. The roles of cyclin-dependent kinases in cell-cycle progression and therapeutic strategies in human breast cancer. Int. J. Mol. Sci. 2020, 21, 1960. [CrossRef]

32. Wood, D.J.; Endicott, J.A. Structural insights into the functional diversity of the cdk-cyclin family. Open Biol 2018, 8, 180112. [CrossRef]

33. Dong, P.; Zhang, C.; Parker, B.T.; You, L.; Mathey-Prevot, B. Cyclin d/cdk4/6 activity controls g1 length in mammalian cells. PLoS ONE 2018, 13, e0185637. [CrossRef]

34. Aleem, E.; Berthet, C.; Kaldis, P. Cdk2 as a master of s phase entry: Fact or fake? Cell Cycle 2004, 3, 35-37. [CrossRef] [PubMed] 
35. De Boer, L.; Oakes, V.; Beamish, H.; Giles, N.; Stevens, F.; Somodevilla-Torres, M.; Desouza, C.; Gabrielli, B. Cyclin a/cdk2 coordinates centrosomal and nuclear mitotic events. Oncogene 2008, 27, 4261-4268. [CrossRef]

36. Huang, Y.; Sramkoski, R.M.; Jacobberger, J.W. The kinetics of $\mathrm{g} 2$ and $\mathrm{m}$ transitions regulated by b cyclins. PLoS ONE 2013, 8, e80861. [CrossRef]

37. Francesconi, A.; Kasai, M.; Petraitiene, R.; Petraitis, V.; Kelaher, A.M.; Schaufele, R.; Hope, W.W.; Shea, Y.R.; Bacher, J.; Walsh, T.J. Characterization and comparison of galactomannan enzyme immunoassay and quantitative real-time pcr assay for detection of aspergillus fumigatus in bronchoalveolar lavage fluid from experimental invasive pulmonary aspergillosis. J. Clin. Microbiol. 2006, 44, 2475-2480. [CrossRef]

38. Rodriguez-Diez, E.; Quereda, V.; Bellutti, F.; Prchal-Murphy, M.; Partida, D.; Eguren, M.; Kollmann, K.; Gomez de Cedron, M.; Dubus, P.; Canamero, M.; et al. Cdk4 and cdk6 cooperate in counteracting the ink4 family of inhibitors during murine leukemogenesis. Blood 2014, 124, 2380-2390. [CrossRef]

39. Cerqueira, A.; Martin, A.; Symonds, C.E.; Odajima, J.; Dubus, P.; Barbacid, M.; Santamaria, D. Genetic characterization of the role of the cip/kip family of proteins as cyclin-dependent kinase inhibitors and assembly factors. Mol. Cell. Biol. 2014, 34, 1452-1459. [CrossRef]

40. Bayrak, A.; Oktay, K. The expression of cyclin-dependent kinase inhibitors p15, p16, p21, and p27 during ovarian follicle growth initiation in the mouse. Reprod. Biol. Endocrinol. 2003, 1, 41. [CrossRef] [PubMed]

41. Radhakrishnan, S.K.; Gierut, J.; Gartel, A.L. Multiple alternate p21 transcripts are regulated by p53 in human cells. Oncogene 2006, 25, 1812-1815. [CrossRef]

42. Wirth, M.; Schick, M.; Keller, U.; Kronke, J. Ubiquitination and ubiquitin-like modifications in multiple myeloma: Biology and therapy. Cancers 2020, 12, 3764. [CrossRef]

43. Lub, S.; Maes, K.; Menu, E.; De Bruyne, E.; Vanderkerken, K.; Van Valckenborgh, E. Novel strategies to target the ubiquitin proteasome system in multiple myeloma. Oncotarget 2016, 7, 6521-6537. [CrossRef]

44. Lim, K.S.; Li, H.; Roberts, E.A.; Gaudiano, E.F.; Clairmont, C.; Sambel, L.A.; Ponnienselvan, K.; Liu, J.C.; Yang, C.; Kozono, D.; et al. Usp1 is required for replication fork protection in brca1-deficient tumors. Mol. Cell 2018, 72, 925-941 e924. [CrossRef]

45. Shan, J.; Zhao, W.; Gu, W. Suppression of cancer cell growth by promoting cyclin d1 degradation. Mol Cell 2009, 36, 469-476. [CrossRef] [PubMed]

46. Popov, N.; Wanzel, M.; Madiredjo, M.; Zhang, D.; Beijersbergen, R.; Bernards, R.; Moll, R.; Elledge, S.J.; Eilers, M. The ubiquitinspecific protease usp28 is required for myc stability. Nat. Cell Biol. 2007, 9, 765-774. [CrossRef]

47. Giovinazzi, S.; Morozov, V.M.; Summers, M.K.; Reinhold, W.C.; Ishov, A.M. Usp7 and daxx regulate mitosis progression and taxane sensitivity by affecting stability of aurora-a kinase. Cell Death Differ. 2013, 20, 721-731. [CrossRef]

48. Li, S.; Wang, D.; Zhao, J.; Weathington, N.M.; Shang, D.; Zhao, Y. The deubiquitinating enzyme usp48 stabilizes traf2 and reduces e-cadherin-mediated adherens junctions. FASEB J. 2018, 32, 230-242. [CrossRef]

49. Tada, K.; Okazaki, T.; Sakon, S.; Kobarai, T.; Kurosawa, K.; Yamaoka, S.; Hashimoto, H.; Mak, T.W.; Yagita, H.; Okumura, K.; et al. Critical roles of traf2 and traf5 in tumor necrosis factor-induced nf-kappa b activation and protection from cell death. J. Biol. Chem. 2001, 276, 36530-36534. [CrossRef]

50. Liu, D.; Song, Z.; Wang, X.; Ouyang, L. Ubiquitin c-terminal hydrolase 15 (uchl5) accelerates the growth of endometrial cancer via activating the wnt/beta-catenin signaling pathway. Front. Oncol. 2020, 10, 865. [CrossRef]

51. Liu, C.W.; Jacobson, A.D. Functions of the 19s complex in proteasomal degradation. Trends Biochem. Sci. 2013, 38, 103-110. [CrossRef]

52. Ben-Nissan, G.; Sharon, M. Regulating the 20s proteasome ubiquitin-independent degradation pathway. Biomolecules 2014, 4, 862-884. [CrossRef]

53. Eleuteri, A.M.; Cuccioloni, M.; Bellesi, J.; Lupidi, G.; Fioretti, E.; Angeletti, M. Interaction of hsp90 with 20 s proteasome: Thermodynamic and kinetic characterization. Proteins 2002, 48, 169-177. [CrossRef]

54. Whittier, J.E.; Xiong, Y.; Rechsteiner, M.C.; Squier, T.C. Hsp90 enhances degradation of oxidized calmodulin by the $20 \mathrm{~s}$ proteasome. J. Biol. Chem. 2004, 279, 46135-46142. [CrossRef]

55. Makhnevych, T.; Houry, W.A. The role of hsp90 in protein complex assembly. Biochim. Biophys. Acta 2012, 1823, 674-682. [CrossRef]

56. Prodromou, C. Mechanisms of hsp90 regulation. Biochem. J. 2016, 473, 2439-2452. [CrossRef]

57. Wayne, N.; Mishra, P.; Bolon, D.N. Hsp90 and client protein maturation. Methods Mol. Biol. 2011, 787, 33-44. [PubMed]

58. Proteasome Activity Assay Kit (ab107921). Available online: https://www.abcam.com/proteasome-activity-assay-kit-ab107921. html (accessed on 19 December 2020).

59. Messingerova, L.; Imrichova, D.; Coculova, M.; Zelina, M.; Pavlikova, L.; Kavcova, H.; Seres, M.; Bohacova, V.; Lakatos, B.; Sulova, Z.; et al. Different mechanisms of drug resistance in myelodysplastic syndromes and acute myeloid leukemia. In Myelodysplastic Syndromes; Fusch, O., Ed.; Intech: Rijeka, Croatia, 2016; pp. 181-200.

60. Chen, J.Y.; Lin, J.R.; Tsai, F.C.; Meyer, T. Dosage of dyrk1a shifts cells within a p21-cyclin d1 signaling map to control the decision to enter the cell cycle. Mol. Cell 2013, 52, 87-100. [CrossRef] 
61. Pavlíková, L.; Kyca, T.; Sulová, Z.; Boháčová, V.; Breier, A.; Šereš, M. Different Effect of Tunicamycin on Expression of Proteins Ivolved in Cell Cycle Regulation in Relation to p-Glycoprotein Presence in 11210 Cells. In Proceedings of the World Congress on Cancer Science and Therapy, Bangkok, Thailand, 2-3 December 2019. Int. J. Cancer Treat. 2019. Available online: https: //www.innovationinfo.org/conferenceproceedings/7/1_Lucia_Pavlikova_abstrakt_rim_Lucia.pdf (accessed on 15 May 2021).

62. Beckerman, R.; Prives, C. Transcriptional regulation by p53. Cold Spring Harb. Perspect. Biol. 2010, 2, a000935. [CrossRef]

63. Galanos, P.; Vougas, K.; Walter, D.; Polyzos, A.; Maya-Mendoza, A.; Haagensen, E.J.; Kokkalis, A.; Roumelioti, F.M.; Gagos, S.; Tzetis, M.; et al. Chronic p53-independent p21 expression causes genomic instability by deregulating replication licensing. Nat. Cell Biol. 2016, 18, 777-789. [CrossRef]

64. Gartel, A.L.; Radhakrishnan, S.K.; Serfas, M.S.; Kwon, Y.H.; Tyner, A.L. A novel p21waf1/cip1 transcript is highly dependent on p53 for its basal expression in mouse tissues. Oncogene 2004, 23, 8154-8157. [CrossRef] [PubMed]

65. Lehman, S.L.; Cerniglia, G.J.; Johannes, G.J.; Ye, J.; Ryeom, S.; Koumenis, C. Translational upregulation of an individual p21cip1 transcript variant by gen2 regulates cell proliferation and survival under nutrient stress. PLoS Genet. 2015, 11, e1005212. [CrossRef]

66. Takenokuchi, M.; Miyamoto, K.; Saigo, K.; Taniguchi, T. Bortezomib causes ER stress-related death of acute promyelocytic leukemia cells through excessive accumulation of PML-RARA. Anticancer Res 2015, 35, 3307-3316.

67. Grice, G.L.; Nathan, J.A. The recognition of ubiquitinated proteins by the proteasome. Cell. Mol. Life Sci. 2016, 73, 3497-3506. [CrossRef]

68. Antao, A.M.; Tyagi, A.; Kim, K.S.; Ramakrishna, S. Advances in deubiquitinating enzyme inhibition and applications in cancer therapeutics. Cancers 2020, 12, 1579. [CrossRef]

69. Davis, C.; Spaller, B.L.; Matouschek, A. Mechanisms of substrate recognition by the 26s proteasome. Curr. Opin. Struct. Biol. 2020, 67, 161-169. [CrossRef]

70. Sakata, E.; Eisele, M.R.; Baumeister, W. Molecular and cellular dynamics of the 26s proteasome. Biochim. Biophys. Acta Proteins Proteom. 2021, 1869, 140583. [CrossRef]

71. Schopf, F.H.; Biebl, M.M.; Buchner, J. The hsp90 chaperone machinery. Nat. Rev. Mol. Cell Biol. 2017, 18, 345-360. [CrossRef]

72. Sanchez, E.R. Chaperoning steroidal physiology: Lessons from mouse genetic models of hsp90 and its cochaperones. Biochim. Biophys. Acta 2012, 1823, 722-729. [CrossRef]

73. Wang, D.; Zong, C.; Koag, M.C.; Wang, Y.; Drews, O.; Fang, C.; Scruggs, S.B.; Ping, P. Proteome dynamics and proteome function of cardiac 19s proteasomes. Mol. Cell. Proteom. 2011, 10, M110.006122. [CrossRef]

74. Pastan, I.; Gottesman, M.M.; Ueda, K.; Lovelace, E.; Rutherford, A.V.; Willingham, M.C. A retrovirus carrying an mdr1 cdna confers multidrug resistance and polarized expression of p-glycoprotein in mdck cells. Proc. Natl. Acad. Sci. USA 1988, 85, 4486-4490. [CrossRef] [PubMed] 